\title{
DISCUSSIE
}

\section{Toekomst van arbeid, toekomst van arbeidsrecht}

\author{
M. De Vos
}

\section{Werk 4.0}

De wereld van werk is in de greep van een revolutie die algemeen doorgaat voor 'Werk 4.0'. Ze wordt omschreven als de grootste omwenteling voor arbeid sinds de eerste industriële revolutie. Er gaat geen week voorbij of een nieuwe studie kondigt de grootschalige verdwijning, verandering of vernieuwing van arbeid, arbeidsorganisatie en arbeidsrelaties aan. Maar wat betekenen al deze voorspelde veranderingen voor de juridische organisatie van de arbeid? Als de toekomst van arbeid verandert, wat wordt dan de toekomst van arbeidsregulering? Aan deze kernvraag poogt deze bijdrage een aanzet te geven. Mijn ambitie is al even bescheiden als ze breed is. Ik vertrek van de grote trendverschuivingen in de wereld van arbeid om hypotheses te formuleren over de toekomst van arbeidsrecht in de brede zin. Ik heb geen pretentie tot volledigheid of techniciteit, wel tot visie en duiding. Dat vergt sterke conceptualisering en reductie, maar ook projectie en veronderstelling.

Donald Rumsfeld en de Irak-oorlog indachtig, bespreek ik zowel het 'gekende bekende' als het 'gekende onbekende' en het 'ongekende onbekende'. Het gekende bekende is de lopende transformatie van de wereld van werk (par. 2). Het gekende onbekende is de paradigmaverandering van het arbeidsrecht die we al vanuit het heden kunnen waarnemen en veronderstellen (par. 3). Het ongekende onbekende is de toekomst van arbeidsrecht op langere termijn, in een wereld waar de essentie van arbeid, werken, werkgeverschap en werknemerschap vervaagt, zonder in futurologie te vervallen (par. 4).

Mijn focus is de westerse wereld die handelsopenheid, markteconomie, welvaartsstaat, arbeidsregulering en vakbondsaanwezigheid combineert. Mijn premisse is dat economische, demografische, sociologische en technologische ontwikkelingen die de wereld van arbeid veranderen, ook het arbeidsrecht zullen veranderen. Arbeidsrecht is voor mij primair een reactieve rechtstak die inspeelt op veranderingen die het niet zelf veroorzaakt. ${ }^{1}$ Maar ik ontken uiteraard niet de vormgevende en controlerende waarde van een rechtstak die historisch als politieke begrenzing van laissez-faire kapitalisme is ontstaan. In die optiek is de toekomst van arbeidsrecht ook de toekomst die we zelf willen (par. 5). Ik doe dus geen voor-

1 M. De Vos, Arbeidsrecht in transitie, in: Liber amicorum Hubert Bocken, Brugge: Die Keure, 2009. 
spellingen, maar formuleer de toekomst van arbeidsrecht in kernthema's en kernvragen.

De toekomst van arbeidsrecht zal de toekomst van arbeid reflecteren zoals die waarneembaar of voorspelbaar is vanuit lopende onderliggende trends die zelf de wereld van arbeid veranderen. Over die megatrends, die lang duren en breed lopen, bestaat grote consensus. ${ }^{2}$ In ons breedbeeldperspectief kunnen we vaststellen dat de westerse wereld van arbeid beweegt door drie simultane tektonische verschuivingen:

- Talentverschuiving, gedreven door demografische vergrijzing en demografische 'vergroening' in subgroepen, generatiediversiteit, massa-immigratie, etnische en culturele hyperdiversiteit, en waardeveranderingen over leven en werken.

- Economische verschuiving, gedreven door globalisering, marktveranderingen, nieuwe bedrijfsstructuren en veranderende human resources (hierna: hr).

- Technologische verschuiving, gedreven door internet, internetplatformen, robotisering, artificiële intelligentie (hierna: AI), hr-tech, 'big data', 3D-printing, nanotechnologie, genetica en biotechnologie.

In het navolgende bespreek ik die megatrends vanuit hun betekenis voor arbeid en vertaal die vervolgens naar megatrends voor arbeidsrecht.

\section{De toekomst van arbeid}

\subsection{Talentverschuiving}

Talentverschuiving illustreert hoe economie en arbeid worden gedreven door demografie en sociologie. De grote naoorlogse babyboomgeneratie - haar opkomst, haar loopbanen en thans haar geleidelijke pensionering - trekt een diep generatiespoor door de wereld van werk. In de periode die voor ons ligt, leidt dat spoor vooral naar de sociale zekerheid en haar betaalbaarheid in een context van repartie. De werkende Europeaan leeft gemiddeld tien jaar langer en werkt gemiddeld tien jaar minder dan in $1970 .{ }^{3}$ Zolang de levensverwachting van de mens en dus van gepensioneerden blijft stijgen, en zolang de sociale zekerheid niet fundamenteel richting kapitalisatie kantelt, zullen meer actieve loopbaanjaren die meer bijdragen aan de pensioenfinanciering en andere sociale bescherming een kernmissie van arbeidsrecht en arbeidsorganisatie blijven.

De generatiewissel die de pensionering van de babyboomers betekent, confronteert de arbeidsmarkt voor de eerste keer met een plafonnerende beroepsbevolking in de successie van leeftijdscohorten: voor de Europese Unie een verlies van 30 miljoen mensen op actieve leeftijd tegen 2050. Niet voor de laatste keer. Met de babyboomers is de daling van de nataliteit onder de natuurlijke vervangingsra-

2 Voor een overzicht, zie bijvoorbeeld Federal Ministry of Labour and Social Affairs, White Paper Work 4.0, Berlijn 2017; National Academies of Sciences, Engineering, and Medicine, Information Technology and the U.S. Workforce: Where Are We and Where Do We Go from Here?, Washington DC: The National Academies Press, 2017; World Economic Forum, The Future of Jobs, 2016. ILO, The Future of Work we want, 2017. 
tio ingezet om (vooralsnog) daaronder te blijven. De toekomst van arbeid zal daarom plaatsgrijpen op een arbeidsmarkt met weinig spontane generatiegroei in een verouderende beroepsbevolking, en in landen zoals Duitsland of Italië zelfs met een significante daling van de globale beroepsbevolking. Immigratie en het opvijzelen van het aandeel van de bevolking dat daadwerkelijk actief is, zijn dan de enige remedies: twee evidente kernthema's voor arbeidsmarktbeleid en arbeidswetgeving in de komende decennia. Zonder demografische groei is economische groei uitsluitend afhankelijk van activiteitsverbetering en productiviteitsgroei.

Immigratie is niet alleen kwantitatief maar ook kwalitatief een uitdaging voor het toekomstige arbeidsaanbod in onze economieën. West-Europese landen, ooit de kernlanden van emigratie, kennen al enkele decennia historisch hoge immigratiesaldi. Maar kwetsbare geografie, bevolkingsexplosies aan buitengrenzen, vervolgmigratie, humanitaire migratie en beleidsmanco's over heel het spectrum hebben immigratie niet tot een oplossing, maar tot een probleem voor hun arbeidsmarkten gemaakt. Lage participatie, baanpolarisatie, 'precariteit', werkarme gezinnen, werkende armen, mismatch tussen vraag en aanbod, informele economie, gettovorming, manke mobiliteit en discriminatie zijn de onzalige fenomenen die geassocieerd worden met een bevolkingsaanwas die normaal tot spontane dynamiek zou moeten leiden.

Bovendien verbergt de algemene bevolkingsevolutie een geconcentreerde natuurlijke groei in subgroepen met hogere nataliteitscijfers, de vermelde 'vergroening', precies in die migrantengemeenschappen waar ouders doorgaans achterstand en achterstelling hebben opgelopen. Samenleving noch arbeidsmarkt kan zich de combinatie van vergrijzing en mislukte verkleuring veroorloven. Het staat als een paal boven water dat de economische integratie en arbeidsparticipatie van immigranten en hun nakomelingen een absolute prioriteit zal worden. De vraag zal zijn wat de arbeidswetgeving daarin kan betekenen, wetende dat de gangbare techniek van discriminatieverboden vooral symboliek is: ze bekroont normaliter een culturele progressie, ze forceert die met een juridische stok achter de deur, maar ze biedt geen krachtige hefboom voor actieve integratie.

Demografie, lange tijd een gratis bonus voor de economie en arbeidsmarkt in Europa, wordt dus een malus of minstens een risico. Dat is echt problematisch. We leven intussen in een kenniseconomie en een diensteneconomie. Daarin maakt menselijk talent het verschil en maakt toptalent, geholpen door technologie en globalisering, echt een wereld van verschil. Juist nu talent doorslaggevend wordt, beleven wij een structurele talentverschraling. De Europese Unie kent zowat 9 miljoen werkloze, laaggeschoolde of ongeschoolde jongeren. Het ligt voor de hand dat ook de actieve fase van het leven, en dus ook het arbeidsrecht, zal worden gemobiliseerd voor het compenseren of bestrijden van een talentcrisis die zelfs de unieke democratisering van het onderwijs in Europa niet heeft kunnen vermijden.

Nog daargelaten de impact van technologie op de arbeidsvraag, waarover hierna meer, betekent een tanend talentaanbod een dominante beleidsopdracht van talentontwikkeling. In de hyperdiverse samenlevingen die westerse landen intussen geworden zijn, is dat een complexe uitdaging die ook door culturele factoren 
zal worden beïnvloed. Zo signaleren sociologen veranderende waardepatronen bij de millenniumgeneratie en bij de navolgende generatie $\mathrm{Z}$, die arbeidskwaliteit, welzijn, jobvoldoening, de werk-privébalans, autonomie, tijdssoevereiniteit, persoonlijke flexibiliteit, persoonlijke groei en bedrijfswaarden een meer centrale plaats in de arbeidsorganisatie kunnen doen krijgen. ${ }^{4}$ In een oorlog om talent zal talent meer persoonlijke eisen en voorkeuren kunnen laten gelden. Evoluerende gezinssamenstelling, gezinsverantwoordelijkheden, rollenpatronen en zorgtaken zullen daarbij ook een rol spelen.

Het toenemende belang van etnische subgroepen zal de wereld van arbeid evenmin onberoerd laten. Bijvoorbeeld religie of de positie van de vrouw in moslimgemeenschappen zijn maatschappelijke vraagstukken met een potentieel sterke impact op tewerkstelling, arbeidsmarkt, bedrijven en organisaties. We smaken daarvan al de voorproefjes in de schoolomgeving, waar vragen over etnische en religieuze accommodatie klassieke neutraliteit bemoeilijken. In het algemeen en in vergelijking met het verleden zullen de verwachtingen, voorkeuren en keuzes van werknemers meer divers en persoonlijker worden. Wat dat allemaal betekent voor het geaggregeerde arbeidsaanbod, voor de arbeidsproductiviteit en voor de arbeidskosten, kan niemand berekenen, maar talentverschuiving zal een diepe kwalitatieve verandering voor de wereld van werk inluiden. Die wereld wordt gegarandeerd nog moeilijker en complexer dan dat hij al is.

\subsection{Economische verschuiving}

Economische verschuiving is de laatste decennia vooral gedreven door globalisering. De afbouw van handelsbelemmeringen, de opening van markten in goedkope ontwikkelende landen met omvangrijke arbeidsreserves, en de vrije stroom van investeringskapitaal hebben onze economische structuur en onze bedrijfsstructuren fundamenteel veranderd. Grote verschillen in arbeidskosten met lageloonlanden hebben de westerse industriële productie verminderd, veranderd of verschoven. Internationale bedrijven zijn internationale ketens geworden die verschillen tussen landen gebruiken om winst te maximaliseren, inclusief onderaanneming, outsourcing, offshoring en delokalisatie. Achter een moederhuis of een merk zit een gelaagde arbeidsrealiteit die zowel territoriaal, economisch als juridisch verkaveld is.

In de westerse landen gedijt vooral ofwel hoogproductieve arbeid die profiteert van de schaal- en specialisatievoordelen van globalisering, ofwel laagproductieve arbeid die losstaat van globalisering. Daarenboven polariseert het speelveld er tussen topbedrijven die steeds succesvoller de globalisering benutten en de rest. Succes wordt almaar meer afhankelijk van kennis, creativiteit, innovatie, teamwerk en strategie, factoren die het personeelsmanagement werkelijk hebben getransformeerd. Mede geholpen door de informatie- en communicatietechnologie staat menselijk talent centraal, maakt menselijk talent het verschil en onderscheiden bedrijfskampioenen zich vaak door de mate waarin ze talent kunnen

4 Zie bijvoorbeeld de terugkerende European Values Study. Waardepatronen zullen uiteraard het hele leven van de generaties mee vormen, bijvoorbeeld als studenten en als consumenten, met navenante economische effecten. 
aantrekken en koesteren. ${ }^{5}$ Globalisering heeft arbeidsspecialisatie internationaal gemaakt en de premie voor talent en talentmanagement in de westerse landen vergroot. Dat maakt de betekenis van de geschetste talentverschuiving des te groter.

Als de politieke wereldorde niet destabiliseert en 'deglobaliseert', zullen de grondstromen van de globalisering niet fundamenteel veranderen. Dat betekent niet het einde voor industriële tewerkstelling in het Westen. Hoogkwalitatieve industrie, geholpen door nieuwe hoogtechnologische productieprocessen, zal de grenzen tussen kenniseconomie, diensten en productie in de westerse landen verder doen vervagen. De grootste verandering wordt verwacht uit wat hyperglobalisering is gedoopt. ${ }^{6}$ De legioenen van spotgoedkope arbeidskrachten van een paar decennia geleden zijn intussen een opkomende globale middenklasse van een paar miljard consumenten. Tegen 2025 zal bijna de helft van de wereldwijde consumptie komen uit landen die dertig jaar daarvoor nog in diepe armoede verkeerden. De wereld evolueert naar grote regionale marktzones met eigen productie en eigen afzetmarkten. De strijd om de consument wordt dé wedloop van de hyperglobalisering. Concurrentie tussen landen en sectoren wordt daarin geleidelijk concurrentie tussen bedrijven uit diverse landen, die elkaar minder op de kostprijs van arbeid en meer op kwaliteit en innovatie bekampen, met mondiale topspelers in alle regio's van de wereld.

Hyperglobalisering uit zich minder in stromen van onafgewerkte producten binnen de transnationale waardeketens van multinationals en meer in kwalitatieve internationale economische integratie zoals we die al in de Europese Unie kennen. Globalisering en hyperglobalisering hebben internationale concurrentie en internationale handel als gemene deler. Dat overgiet hun hele arbeidswereld met vereisten van specialisatie, wendbaarheid, flexibiliteit en volatiliteit, zowel voor het arbeidsmarktbeleid als voor de arbeidsorganisatie. Die gekende fenomenen worden nog belangrijker wanneer hyperglobalisering de concurrentie nog verder opdrijft en succes nog meer afhankelijk maakt van buitenlandse klandizie. Hyperglobalisering maakt internationaal succes meer persoonlijk, want bedrijfsgebonden globalisering maakt internationaal succes meer politiek want is gebonden aan algemene marktfactoren. Beide impliceren belangrijke aanpassingsvereisten voor werknemers en voor bedrijven.

Globalisering heeft geleid tot complexe bedrijfsstructuren waarin arbeid in een keten wordt uitgerekt, vooral in de industrie. Onder hyperglobalisering zou die trend zich verspreiden naar kennissectoren en naar het microniveau van individuele contracten. Bedrijfsstructuren zouden evolueren naar kneedbare ecosystemen die de economische omstandigheden volgen. Daarbij zouden planning, organisatie, productie, diensten en consumptie niet langer gescheiden verlopen, maar interageren en connecteren. Via outsourcing, aanneming, freelancers en een panoplie van ad-hoccontracten zou een toenemend deel van de bevolking door het beroepsleven walsen als tijdelijke puzzelstukken in een steeds veranderend

5 Zie uitgebreid in M. De Vos, Ongelijk maar fair, Lannoo Campus 2015.

6 Zie bijvoorbeeld A. Subramanian \& M. Kessler, The Hyperglobalization of Trade and its Future, Global Citizen Foundation 2013. 
mozaïek van economische samenwerkingsverbanden. Flexibele arbeid wordt dan niet langer een buffer binnen en voor de organisatie, maar de kern van de bedrijfsorganisatie en de expressie van arbeidsverdeling over organisaties heen. ${ }^{7}$

\subsection{Technologische verschuiving}

Technologische verschuiving wordt alom als de meest fundamentele en 'disruptieve' megatrend gezien. Dat mag verbazen. Technologische innovatie transformeert arbeid al meer dan vierhonderd jaar. Oude technologie verschrompelt, tot de nieuwe technologie zelf begint te verouderen en de cyclus herbegint. Bij elke vernieuwingsronde is de impact op arbeid dezelfde. Banen in de oude technologie worden schaarser, om uiteindelijk te verdwijnen. Dat is de minzijde. De pluszijde zit bij de technologische vernieuwing zelf. Die vergt en schept nieuwe banen. Er zijn geen spinsters meer, maar weefgetouwen betekenen grondstoffen, constructie, elektriciteit, design, productie, bediening en onderhoud. Er zijn geen koetsenmakers en koetsiers meer, maar wel megafabrieken voor autoassemblage, netwerken van toeleveranciers, studio's vol ontwerpers, gigantische staalproducenten, verffabrieken, gespecialiseerde machinebouwers, autohandelaren, en ga zo maar door. De beste innovaties groeien uit tot hele nieuwe sectoren met hele nieuwe waardeketens.

Dankzij de technologie en het kapitaal dat daarachter zit, zijn de nieuwe banen doorgaans productiever dan de oude: ze brengen meer economische waarde op. Die marge is batig voor de winstgevendheid van de bedrijven, voor het inkomen van de werknemers en voor de hele samenleving die van beide profiteert. Technologische vernieuwing is het kloppende hart van de kapitalistische vooruitgangsmachine, de basis van onze welvaartsgroei doorheen de eeuwen. Ondanks bijwijlen zware aanpassingsschokken is haar saldo voor arbeid zonder meer indrukwekkend: het aantal werkende mensen in verhouding tot de totale bevolking en de gemiddelde kwaliteit van het werk is er stelselmatig op vooruitgegaan. ${ }^{8}$

Tot op heden is geen kentering in die globale kwantitatieve en kwalitatieve vooruitgang waarneembaar. Wel integendeel, mede gedreven door de demografische transitie van de pensionerende babyboomers, kampt de ontwikkelde wereld niet zozeer met arbeidsschaarste maar met talentschaarste. En toch leeft dezer dagen de vrees of de overtuiging dat technologie voor arbeid en voor de arbeidende mens een existentiële bedreiging kan gaan vormen.

De inschatting dat het 'deze keer anders is', wordt gevoed door verschillende vaststellingen of verwachtingen. Nieuwe technologie reikt tot diep in de diensteneconomie die de ruggengraat van onze moderne samenleving is, terwijl eerdere technologie meer de landbouw en de industriële economie raakte. Het internet en de internetplatformen digitaliseren en versnipperen arbeidsrelaties tot een geautomatiseerde stroom van vluchtige taken. Het rekenvermogen van computers, gecombineerd met doorbraken in sensoren, mobiele communicatie, connectiviteit

$7 \quad$ Zie D. Vinik, The Real Future of Work, Politico 2018.

8 Voor een overzicht, zie bijvoorbeeld De Vos 2015; J. Appleby, The Relentless Revolution. A History of Capitalism, Norton 2010. Voor vooruitgangsdata, zie bijvoorbeeld recentelijk S. Pinker, Enlightenment now, Allen Lane 2018. 
en de zogenoemde 'blockchain'-technologie, maakt zodanige sprongen dat artificiele intelligentie menselijke intelligentie zou kunnen vervangen in jobs die tot nog toe buiten het bereik van technologie zijn gebleven. Robots, lange tijd spreekwoordelijke meiden voor simpel maar zwaar werk, zouden op de rand staan van datgene wat hun verspreiding exponentieel zou doen vermenigvuldigen: menselijke handelingen na-apen.

Tel dat allemaal op en voor het eerst in de geschiedenis zou technologische innovatie geen positief maar negatief saldo kunnen genereren. Daarover bestaat wel geen vleugje eensgezindheid. ${ }^{9}$ Optimisten verwachten alleen meer creatieve destructie, de combinatie van banenverlies en banenwinst, maar wel met een positieve eindbalans. Pessimisten zien bepaalde beroepsgroepen en sectoren als met uitsterven bedreigd. Doemdenkers voorspellen dat de werkende mens het lot van het paard wacht: ooit een productief economisch wezen, daarna overbodig, tenzij voor vrije tijd.

Alleen in die totale apocalyps, die we hierna in paragraaf 4 als onwaarschijnlijk duiden, wordt arbeidsrecht uiteindelijk zinledig. In alle andere scenario's wordt arbeidsrecht alleen maar belangrijker. Wat alle visies verenigt, is immers de verwachting dat de normale cyclus van jobvernietiging, jobcreatie en jobtransitie, eigen aan elke technologische innovatie, structureel en fundamenteel zal versnellen, verdiepen en verbreden naar zowat alle sectoren, beroepen en opleidingsniveaus. Tegen 2030 zouden wereldwijd, aldus een bekende schatting, tussen 75 en 375 miljoen werknemers van baan veranderen door technologische verschuiving. ${ }^{10}$ Daarbovenop zullen veel banen die niet verdwijnen wel sterk inhoudelijk veranderen en dus evenzeer grote aanpassingen vergen. ${ }^{11}$ Daarin ligt telkens een centrale rol voor het arbeidsrecht.

Het samenspel van deze megatrends, die we gemeenzaam als 'Werk 4.0' benoemen, opent enorme mogelijkheden om anders te gaan werken en ondernemen: meer productief, meer flexibel, meer verbonden, meer internationaal. De centrale positie van arbeid en van op arbeid gebaseerde sociale bescherming in de westerse samenleving, economie en welvaartsstaat maakt deze verschuivingen echter tot fundamentele transformaties, voor personen, voor bedrijven of organisaties, voor overheden of landen. Fundamentele verandering in de wereld van werk betekent enorme uitdagingen voor aanpassing, investering en vernieuwing op alle niveaus van de samenleving. Uiteraard zullen de aard, de omvang, de timing en de impact van die verandering verschillen tussen landen, tussen regio's, tussen economische sectoren en tussen bedrijven. In wat volgt, overstijg ik verschillen om te schetsen hoe het arbeidsrecht als reactieve rechtstak kan worden gemobiliseerd om de uitdagingen van Werk 4.0 te begeleiden of te beantwoorden.

9 Voor een overzicht van de diverse studies en hun uiteenlopende schattingen, zie European Parliamentary Research Service, The impact of new technologies on the labour market and the social economy, European Parliament 2018; E. Winick, Every study we could find on what automation will do to jobs, in one chart, MIT Technology Review 2018.

10 McKinsey Global Institute, Jobs lost, jobs gained: Workforce transitions in a time of automation, McKinsey 2017.

11 Zie L. Nedelkoska \& G. Quintini, Automation, skills use and training (OECD Social, Employment and Migration Working Papers), Parijs: OECD Publishing 2018. 


\section{De toekomst van arbeidsrecht}

\subsection{Activeringsrecht}

Economische, technologische en internationale veranderingen zijn niet nieuw: ze zijn van alle tijden. De convulsies die de megatrends van Werk 4.0 op de wereld van arbeid loslaten, zijn weliswaar groter en reiken dieper, maar het arbeidsrecht heeft al eerder met disruptie moeten leren omgaan. In die optiek zal de nabije toekomst van het arbeidsrecht lijken op een herhaling of versterking van zijn verleden. Dat verleden heeft arbeidsrecht op de weg naar arbeidsmarktrecht gezet. De massawerkloosheid na de olieschokken van de jaren zeventig van de vorige eeuw, de postindustriële reconversie, de opkomst van de kenniseconomie, de internationalisering via de Europese interne markt en de globalisering, de crisis van de welvaartsstaat: in elke cyclus van transformatie is naar het arbeidsrecht gekeken en gegrepen als deel van de oplossing. Doelgroepenbeleid, begeleiding en bescherming bij bedrijfsoperaties, arbeidsbemiddeling en activering: het zijn maar enkele van inmiddels gekende en beproefde recepten van arbeidsregulering die de microrelatie van de arbeidsovereenkomst overstijgt in een macroperspectief van arbeidsmarktverandering.

In de meest recente fase is het perspectief van de arbeidsmarkt gebruikt, niet alleen om het arbeidsrecht te complementeren, maar ook om het te moderniseren. Vanuit het besef dat verandering en onzekerheid de enige zekerheden zijn in moderne open economieën beoogt de zogenoemde 'flexizekerheid' de blijvende inzetbaarheid van mensen op lange termijn. Voor het arbeidsrecht impliceert dat een paradigmaverandering. De primaire missie is niet langer statische baanzekerheid via bescherming tegen verandering, maar dynamische werkzekerheid via ondersteuning bij verandering. ${ }^{12}$ Flexizekerheid concretiseert zich bijvoorbeeld in een nieuwe invulling van ontslagrecht richting baantransitie, in een focus op opleiding en vorming, in een breder spoor voor flexibiliteit en persoonlijke autonomie, en in decentralisering van sociaal overleg.

Daarbij veranderen ook de rollen en de verantwoordelijkheden voor de actoren van het arbeidsrecht. Voor de overheid, die de finaliteit en de inhoud van de regulering van de arbeidsverhouding stuurt en die de collectieve missie van duurzame inzetbaarheid transversaal buiten de arbeidsmarkt gestalte moet geven in onderwijs, in sociale bescherming en in publieke dienstverlening. Voor werkgevers en werknemers, wier juridische status en verantwoordelijkheden voortaan hun persoonlijke arbeidsrelatie overstijgen. Voor de sociale partners, bij het onderhandelen over arbeidsvoorwaarden, bij het opzetten van aanvullende sociale bescherming, bij ontslagen en veranderingsprocessen, en in hun functie van alternatieve arbeidsregulator. Voor arbeidsbemiddelaars, administraties en publieke dienstverleners, die bijdragen aan de ontwikkeling en economische inzetbaarheid van mensen, in welke levensfase ook.

We moeten het warm water niet opnieuw uitvinden. Veel van de inzichten en doelstellingen die de agenda van flexizekerheid schragen, zijn ook toetsstenen 
voor het arbeidsrecht van Werk 4.0. Daar is ook ruimte voor. Tussen de retoriek en publiciteit rond flexizekerheid en de realiteit in de wetboeken en op de werkvloer heeft altijd een flinke afstand bestaan. De weerstand tegen verandering en zelfs de contestatie van de fundamentele paradigmapremisse zijn reëel. We moeten die weerstand overwinnen.

De besproken megatrends maken de overkoepelende maatschappelijke uitdaging glashelder: kansen voor iedereen promoten in de structurele veranderingen en ons aller vermogen tot aanpassing aan die veranderingen versterken. Dat is vanzelfsprekend een uitdaging die dwars door een mensenleven en het hele beleidsspectrum loopt. Het gaat fundamenteel om een kanteling van de welvaartsstaat richting een investeringsstaat die systematisch, preventief en curatief inzet op de ontwikkeling van menselijk talent. Het gaat om veel meer dan arbeidsrecht, maar het arbeidsrecht is er wel een belangrijk onderdeel van.

Vanuit het perspectief van de arbeidsmarkt wordt transitie een belangrijke missie van het arbeidsrecht van de nabije toekomst. Tussen jobs laveren, werkloosheid vermijden of overwinnen, vanuit inactiviteit op de arbeidsmarkt komen, uit het onderwijs naar de arbeidsmarkt stromen, uit immigratie naar participatie stappen, vanuit een zorgfase naar een arbeidsfase evolueren, als vluchteling aan de slag gaan: het zijn variaties op een en hetzelfde transitiethema. Transitie zal van overheersend belang zijn om onze diverse beroepsbevolking maximaal kansen op inclusie en onze veranderende economie maximaal kansen op inzetbaar talent te bieden.

We gaan deze uitdaging niet aan zonder ervaring. Onder de noemer van 'activering' heeft het arbeidsmarktbeleid de afgelopen decennia breed geëxperimenteerd met maatregelen, met rechten en plichten, om werkkansen en werkbereidheid te faciliteren. De resultaten daarvan zijn gemengd. ${ }^{13}$ De opdracht luidt om breder en beter te doen in de toekomst. Beter doen betekent bijvoorbeeld meer inzetten op geografische mobiliteit, vacatures sneller invullen, reguleringsbarrières die beroepen of sectoren afschermen voor nieuwkomers verlagen, preventieve activering organiseren om op verandering te anticiperen, en mensen in inactiviteit reactiveren. ${ }^{14}$

Reactivering wordt een echte prioriteit, omdat de vermelde talentschaarste onze dwingt niet-actieve groepen op de arbeidsmarkt te krijgen. Niet zozeer werkloosheid, maar activiteitsgraad wordt de belangrijkste beleidsbarometer. Een gepaste mix van financiële prikkels, begeleiding, opleiding, arbeidsflexibiliteit en beroepstoegankelijkheid zal nodig zijn. ${ }^{15}$ We zijn al gewoon aan doelgroepen die specifieke inspanningen vergen. Als de technologische revolutie zou leiden tot grootschalige technologische werkloosheid en inactiviteit, zullen we ongetwijfeld nieuwe doelgroepenmaatregelen nemen. De lessen van zowel succesvolle als

13 Zie bijvoorbeeld het overzicht in A.J.G. Brown \& J. Koettl, Active labor market programs employment gain or fiscal drain?, IZA Journal of Labor Economics 2015, 4, p. 12.

14 Zie bijvoorbeeld C. Frey, The Future of Jobs and Growth: Making the Digital Revolution Work for the Many, G20 Insights 2017.

15 Zie Eurofound, Reactivate: Employment opportunities for economically inactive people, Luxemburg: Publications Office of the European Union 2017. 
gefaalde reconversies van industriële naar postindustriële tewerkstelling zullen daarbij goed van pas komen.

De kruising van de arbeidsmarkt met de besproken megatrends zal verschillende groepen in de samenleving verschillend treffen. Opleidingsniveau, geslacht, geografische regio, economische sector of leeftijd zal de uiteindelijke impact van Werk 4.0 kleuren. Anno 2018 staat technologie bijvoorbeeld gelijk met een genderkloof en een leeftijdskloof op de arbeidsmarkt. Als dat niet verandert, wordt die kloof een ravijn. Meer actieve vrouwen en langere loopbanen worden niet alleen sociaal en budgettair wenselijk. In het tijdperk van Werk 4.0 zijn ze een existentiële noodzaak tegen een achtergrond van talenttekort. Gerichte activeringsprioriteiten zijn dan logisch.

Dat alles wordt een collectieve en holistische opdracht die zowel de arbeidsmarkt als de klassieke tussenschotten in sociale bescherming overstijgt. Ze zal transversaal gelden, niet alleen voor werkzoekenden in werkloosheid, maar ook voor vluchtelingen in erkenning, voor immigranten in inburgering, voor steuntrekkers in inactiviteit, voor langdurig zieken in herstel, en zo meer. Activering 2.0 verloopt het best langs één contactloket waarachter alle bevoegdheden en diensten schuilen. Ze gebeurt op maat, investerend, met wortel en stok, proactief en preventief voor probleemgroepen en probleemregio's, curatief voor anderen. Ze wordt sterker ingebed in alle uitkeringsregimes. Ze vergt meer aandacht voor effectiviteit en efficiëntie, meer beleidsdata en meer verantwoordelijkheid bij begeleiders en coaches.

Activering 2.0 is ook naadloos verbonden met ontslagrecht. In de hele OESO (Organisatie voor Economische Samenwerking en Ontwikkeling) is de naald van ontslagregulering nauwelijks verschoven in de laatste twintig jaar: een treffende illustratie van theorie versus praktijk in flexizekerheid. ${ }^{16}$ Zowel individuele als collectieve ontslagen zijn nog altijd vooral een gevecht over compensatie in plaats van transitie. Anderzijds wordt ontslag op grote schaal vermeden via tijdelijke contracten, vooral aan het begin van het beroepsleven. Activeringsrecht moet ontslagrecht vervangen door transitierecht en moet transitierecht veralgemenen voor elk type van arbeidsovereenkomst. Alleen dan kan wat een kritieke arbeidsmarktnoodzaak is ook doordringen tot elke arbeidsrelatie.

\subsection{Loopbaanrecht}

Wie de arbeidsmarkt als uitgangspunt neemt, legt de klemtoon niet op de baan maar op de loopbaan. Ik verwacht dat de loopbaan het dominante perspectief op arbeidsregulering zal worden. Daarvoor zijn er nu al goede argumenten. Achter een globale arbeidsmarkt met gemiddeld indrukwekkende resultaten van jobcreatie en participatie schuilt immers een toenemende diversiteit van flexibele en tijdelijke contracten, dubbele banen, zelfstandigen, freelancers en deeltijders. De trend is niet overal even uitgesproken, is in sommige landen eerder een tijdelijk crisisfenomeen, en is voor de betrokkenen niet altijd een blijvende realiteit. Maar wat we 'flexibele arbeid' noemen, atypisch ten opzichte van de historische norm van vaste voltijdse tewerkstelling, is in opmars. In Europa en in de VS kan tot een 
kwart van de beroepsbevolking al met een of andere vorm van flexibele arbeid geassocieerd worden, in totaal meer dan 160 miljoen mensen. ${ }^{17}$

De trend naar diversifiëring van arbeidsrelaties zal versterken door de megatrends achter Werk 4.0. Zowel langs de aanbodzijde van talent als langs de vraagzijde van economie staat Werk 4.0 voor variatie en diversiteit, overgoten met een saus van globalisering en technologie die arbeid tot in het DNA flexibiliseert. Het klassieke onderscheid tussen vaste en atypische arbeid zal verder vervagen. Arbeidsrelaties zullen meer voor taken, opdrachten, pieken en periodes staan. Atypisch wordt de nieuwe typische arbeid. Dat heeft zowel positieve als negatieve kanten. Positief is een betere toegang tot de arbeidsmarkt en een vlottere combinatie van werken en leven. Waar kenniseconomie en technologie elkaar vinden, bij hoogopgeleide mobiele kenniswerkers en zelfstandige professionals, kan flexibel of zelfstandig werken zelfs een regelrechte levensstijl worden. In die groep is de opkomst van freelancewerk een droom van loopbaanvariatie, keuzevrijheid en persoonlijke ontplooiing die ook algemeen de economie dient. ${ }^{18}$ Jongeren in het bijzonder zijn gecharmeerd door de mogelijkheid om zelf de controle over baan en loopbaan te kunnen behouden. ${ }^{19}$

Negatief is het risico van segmentering op de arbeidsmarkt, waarbij een deel van de beroepsbevolking genoegen moet nemen met onzekere en minder betaalde banen zonder veel loopbaanperspectief. Hardnekkige achterstelling van subgroepen is een pijnlijke realiteit van de hedendaagse arbeidsmarkt, die deels overlapt met de toename van atypische arbeid. Baanpolarisatie door een combinatie van onaantrekkelijke laagbetaalde banen, verdwijnende routinebanen in het midden en aantrekkelijke hoogbetaalde banen hogerop, is al waarneembaar. Ze zal voorspelbaar toenemen als de hyperglobalisering en de technologisering van werk doorzetten zonder aangepast beleidskader. ${ }^{20}$

De paradox van het hedendaagse arbeidsrecht is dat het de arbeidssegmentering niet zozeer opvangt, maar eerder verergert. Onder druk van de vermelde megatrends hebben continentaal-Europese landen gekozen voor asymmetrische liberalisering, die de mogelijkheid voor atypische arbeid vergroot naast de klassieke 'typische' arbeid waarvan het juridisch statuut grotendeels ongewijzigd is gebleven. De proliferatie van alternatieve contractformules geeft een aanzuigeffect dat de polarisatie tussen succesvolle insiders en kansarme outsiders op de arbeidsmarkt vergroot. De switch van arbeidsrecht naar loopbaanrecht moet dat perverse effect keren. De keuze en diversiteit onderhouden die mensen autonomie geven, de dynamiek en variatie faciliteren die de economie vergt, en tegelijkertijd vermijden dat mensen flexibiliteit ondergaan en gevangen geraken in fragmentarische arbeidsrelaties zonder basisrechten: dat is de centrale driehoeksstelling van loopbaanrecht.

17 Aldus McKinsey Global Institute, Independent work: choice, necessity, and the gig economy, 2016.

18 Zie The Adecco Group \& LinkedIn, Flexible Working: A career and lifestyle pathway, 2018.

19 Zie ManpowerGroup, Gig Responsibly. The Rise of NextGen Work, 2018.

20 Zie European Parliamentary Research Service 2018; M. Lawrence e.a., Managing Automation. Employment, inequality and ethics in the digital age, Institute for Public Policy Research 2017. 
Vanuit de premisse dat Werk 4.0 de biodiversiteit aan banen in de economie verder zal doen toenemen, moet de aandacht alweer verschuiven van de baan naar de loopbaan. Arbeidsrecht zal dan barrières voor flexibele arbeidsrelaties algemeen verminderen, garanties van stabiele rechten over de barrières heen vergroten en meer inzetten op doorlopende inzetbaarheid van werknemers op de arbeidsmarkt. Daarin kent het arbeidsrecht een precedent. De regulering van uitzendarbeid illustreert de werking van arbeidsrecht als loopbaanrecht. Ze faciliteert flexibiliteit, maar begrenst die ook, ze maakt een gemeenschappelijk speelveld van minimale rechten en garandeert daarvan de overdraagbaarheid bij verandering van opdrachtgever. Tegelijkertijd betrekt ze een derde partij die de verantwoordelijkheid draagt voor de continuïteit van de bescherming in de discontinuïteit van de tewerkstelling.

Om nog verder richting loopbaanrecht te evolueren moeten continuïteit en overdraagbaarheid van bescherming ook bij sprongen tussen sociale statuten mogelijk worden. In essentie moet economische activiteit, ongeacht het statuut, de duurtijd van de arbeid of de identiteit van de partijen, gekoppeld kunnen worden aan voordelen die beantwoorden aan drie vereisten: de werknemer of een anderszins economisch actieve persoon moet persoonlijk zijn voordelen bezitten en meenemen, zijn economische tegenpartij moet aan die voordelen bijdragen a rato van de mate waarin beide partijen samenwerken, en de voordelen moeten minstens gedeeltelijk onafhankelijk zijn van de juridische kwalificatie van die samenwerking. Eerder dan basisbescherming bij arbeid fundamenteel te verkavelen tussen bijvoorbeeld werknemers, zelfstandigen, freelancers en ambtenaren, worden juridische statuten overstegen en verenigd via gedeelde rechten die de loopbaanvariatie volgen en dienen. Daarenboven moet de minimale bescherming inhoudelijk meer focussen op loopbaanontwikkeling en brede inzetbaarheid op de arbeidsmarkt, zodat 'flexibele arbeid' meer betekent dan alleen anders arbeiden.

Ook op dat vlak is de evolutie van het arbeidsrecht al begonnen. In diverse Europese landen wordt geëxperimenteerd met aanzetten van wat elders als een loopbaanrekening is verdedigd. ${ }^{21}$ De volwassen loopbaanrekening is een multifunctioneel loopbaaninstrument dat een financiële hefboom biedt voor het opvangen en ondersteunen van de loopbaanontwikkeling op maat van de persoon. De loopbaanrekening kan aangesproken worden voor opleiding en vorming, voor verloven en arbeidsduurvermindering, voor arbeidsformules op maat, bij ontslag of pensioen, enzovoort. Ze vervangt of versterkt collectieve systemen die met veralgemeende doelgroepen werken, die suboptimaal renderen ten aanzien van de individuele carrièrenoden en die het persoonlijke loopbaangedrag van werknemers artificieel beïnvloeden met perverse effecten voor de hele arbeidsmarkt.

Een uitgebouwde loopbaanrekening geeft de loopbaan een centrale plaats in de toekomst van het arbeidsrecht. Loopbaancompetenties, loopbaanontwikkeling, loopbaanplanning, loopbaanmanagement, eindeloopbaan en loopbaantransities: alles wordt gefaciliteerd. De loopbaan is een gedeelde verantwoordelijkheid die de individuele arbeidsrelatie overstijgt. Daarom komt de loopbaanrekening tot stand

21 Zie M. De Vos, Naar een betere arbeidsmarkt, in: Roadmap 2014-18, Brussel: Itinera Institute 2014. 
in een driehoeksverhouding tussen de werknemer, de werkgever en de overheid. Ze kan ook andere partijen zoals verzekeraars of hr-dienstverleners betrekken. Aan de loopbaanrekening zal de werknemer zelf bijdragen, enerzijds financieel en anderzijds door te werken, want het is precies via werk dat de opbouw van de loopbaanrekening door de werkgever en/of overheid zal gebeuren. Betrokkenheid van de werknemer illustreert hoe de evolutie van arbeidsrecht naar loopbaanrecht niet alleen nieuwe rechten, maar ook nieuwe verantwoordelijkheden inhoudt.

De werknemer wordt medeverantwoordelijk voor het opsparen en besteden van de middelen. Dat is de beste garantie voor doelmatigheid in het licht van zijn persoonlijke loopbaansituatie. Dat is het grote verschil met collectieve systemen die door derden, in het bijzonder door de belastingbetalers, worden gedragen. De financiële bijdragen van de werknemer kunnen bestaan uit een loonpercentage en/of uit het inruilen van tijd voor geld. De loopbaanrekening kan met andere woorden ook het meer gekende 'tijdsparen' toelaten, waarbij de werknemer verlofdagen, rustdagen of andere periodes vrijwillig omruilt voor een kapitaal dat hij later kan gebruiken om langere tijd niet of minder te werken.

Afhankelijk van de concrete loopbaandoelstelling kan de financiering in de vermelde driehoeksrelatie variëren, en kunnen bestaande collectieve systemen worden afgebouwd, omgebouwd of afgeschaft. De wirwar van schorsingen, verloven, opleidingen en arbeidsduurverminderingen die het moderne arbeidsrecht tot een kluwen maakt en die de arbeidsmarkt vaak nodeloos met obstakels voor mobiliteit bezwaart, kan via de loopbaanrekening grondig vereenvoudigen. Daarmee worden opnieuw de draagbaarheid en de fluïditeit van sociale bescherming doorheen banenwissels verbeterd.

Voor de werknemer betekent de loopbaanrekening een ondersteunde cultuurshift richting anders en duurzaam werken, met meer talentonderhoud, meer vrijwillige verandering en minder gedwongen transitie. Voor de overheid is de loopbaanrekening een flexibele katalysator voor beleid dat de inzetbaarheid op de arbeidsmarkt wil bevorderen, dat langer werken wil belonen en dat vroeger stoppen wil ontraden. De overheid kan bijdragen aan de rekening 'oormerken' om activerende loopbaandoelstellingen te ondersteunen. Ze kan de rekening extra spijzen bij bijzondere loopbaanincidenten of haar gebruiken als 'loonverzekering' of 'aanpassingsverzekering' bij arbeidsmarktschokken. Ze kan de rekening doortrekken in andere domeinen zoals gezinsbeleid, of gebruiken als quasi-universeel instrument voor gepersonaliseerd sociaal beleid.

Doordat ze aan elke vorm van arbeid kan worden gekoppeld, zal de loopbaanrekening loopbaanontwikkeling ook bij 'atypische' tijdelijke arbeid onderhouden. Het gekende nadeel dat werkgevers minder geneigd zijn in de toekomst van tijdelijk personeel te investeren, wordt daarmee overwonnen. Voor de werkgever is de loopbaanrekening een instrument om talentmanagement te integreren in het courante personeelsbeleid. Wanneer arbeid algemeen diversifieert, evolueren organisaties en bedrijven naar talentecosystemen met lagen en gradaties van samenwerking die integratie en coördinatie vergen. Ook daarin kan de loopbaanrekening een faciliterende rol spelen.

Loopbaanrecht zal zowel onvrijwillige als vrijwillige arbeidsmobiliteit ondersteunen. De veranderingen van Werk 4.0 zullen immers ook veel kansen bieden. 
Werknemers moeten gemakkelijker zelf kansen kunnen grijpen. Het klassieke arbeidsrecht is streng voor werknemers die in meer dan hun arbeidsovereenkomst geïnteresseerd zijn. Concurrentieregels belemmeren werknemers vaak om hun talenten naast of na de arbeidsovereenkomst elders te verzilveren. De regulering van intellectuele eigendom en de bescherming van professionele informatie als bedrijfsinformatie kunnen werknemers afsnijden van loopbaantools die ook hun persoonlijke verdienste zijn. Zelf ontslag nemen heeft vaak onzalige consequenties, zowel inzake opgebouwde rechten als voor bescherming tegen werkloosheid. Banen combineren en tussen banen willen circuleren, vergt complete verstandhouding tussen partijen. Kortom: de wettelijke balans tussen de contractspartijen van de arbeidsovereenkomst is eenzijdig en faciliteert geenszins een loopbaanbenadering. Modernisering dringt zich op. Daarin kan de loopbaanrekening zowel financieel als organisatorisch empowerment bieden voor de werknemer die voor zijn eigen kans wil gaan.

In vergelijking met de gestandaardiseerde, collectieve bescherming die aan een baan is verbonden, impliceert een gepersonaliseerde, individuele rekening die aan de loopbaan is verbonden meer complexiteit in beheer en organisatie. Dat is een te verhelpen nadeel. We zijn al goed vertrouwd met dienstverlenende derden die de organisatiecomplexiteit van arbeidsrelaties overnemen en beheren. Ongetwijfeld zal loopbaanrecht een biotoop van loopbaandienstverlening inhouden. Maar doorslaggevend wordt het organisatiepotentieel van technologie. De data- en communicatietechnologie die arbeid transformeert, zal ook de organisatie van arbeid vergemakkelijken. Technologie is de opstap naar meer kwaliteit in de arbeidsorganisatie en arbeidshuishouding. Dat vergt enige toelichting.

\subsection{Arbeidskwaliteitsrecht}

Wie de loopbaan en dus de lange termijn als toetssteen aanhoudt, beseft dat de kwaliteit van arbeid een belangrijk aandachtspunt is. Onze beleidsblik op de arbeidsmarkt wordt gedomineerd door kwantitatieve maatstaven zoals werkloosheid, activiteit, leeftijd, inkomen, anciënniteit en productiviteit. Juridisch is arbeidskwaliteit een centrale component van het arbeidsrecht. De kern van het traditionele arbeidsrecht, met zijn focus op arbeidsvoorwaarden zoals beloning, arbeidsduur en arbeidsomstandigheden, kan voor kwaliteitsregulering doorgaan. Maar deze klassieke kwaliteitscriteria ademen een afkalvend verleden van traditionele arbeid en arbeidsorganisatie, waarin zekere banen, afdoend inkomen en werkgeversverantwoordelijkheid domineren. ${ }^{22}$ Dat maakt ze niet irrelevant. Zolang mensen werken om te leven, zullen met name beloning, arbeidsduur, vakantie en werkomgeving belangrijk blijven. Maar Werk 4.0 verandert banen, diversifieert inkomens en vermenigvuldigt de partijen die bij het verschaffen en organiseren van werk betrokken zijn. We zullen arbeidskwaliteit moeten herbekijken als we de kloof tussen insiders en outsiders op de arbeidsmarkt niet verder willen vergroten en als we arbeidsregulering niet als een rem op economie en 
banencreatie willen hanteren. Daarnaast moeten we onze blik aanscherpen om oude kwaliteitsprincipes naar de nieuwe werkrealiteit te transponeren. ${ }^{23}$

Arbeidskwaliteit vertalen in arbeidsregulering is moeilijk omdat kwaliteit vaak specifiek, relatief, contextueel en deels subjectief is. ${ }^{24}$ Maar moeilijk is niet onmogelijk. We zagen al dat activeringsrecht kwaliteit centraal stelt in de vorm van meetbare effectiviteit en efficiëntie. Wanneer we het perspectief van loopbaanrecht aanhouden, wordt de mate waarin arbeid loopbaanrechten genereert een kwaliteitsmaatstaf. Kwaliteitsdimensies liggen daarbij voor de hand. Opleiding, vorming, loopbaanontwikkeling en loopbaandiensten moeten immers resultaten bereiken. Doorheen de variatie van arbeidsstatuten zijn autonomie en persoonlijke flexibiliteit kwaliteitskenmerken. Gezondheid, welzijn en preventie evolueren mee met de aard en de organisatie van de arbeid. Parameters van sociale inclusie en gelijke kansen zijn denkbaar. Ook voor de interactie met technologie en voor het gebruik en de bescherming van personeelsdata zijn kwaliteitsnormen logisch.

In de penetratie van arbeid en arbeidsrelaties door informatie- en communicatietechnologie kent arbeidskwaliteitsrecht zijn grootste medestander. Voor de organisatie van arbeid is technologie een instrument voor tijdsautonomie, tijdsflexibiliteit, locatieflexibiliteit en de vlotte combinatie van leven en werken. Dat is een grote kwaliteitsbonus, want arbeidsautonomie, arbeidswelzijn en gezondheid gaan hand in hand. ${ }^{25}$ Voor de arbeid zelf biedt technologie een kwalitatieve sprong voorwaarts in de ondersteuning van mens door machine en in de interactie van mens met machine. Technologie zal de werkende mens helpen; denk maar aan digitale assistenten, gezondheidssensoren, ongevalspreventie en efficiënte mobiliteit. De mens en intelligente machines zullen collega's worden. Collaboratieve robots of co-bots zullen de afstand tussen mens en machine overbruggen. Ze zullen de mens aanvullen of vervangen in zware taken. Ze zullen onze fysieke, zintuigelijke en intellectuele vermogens vergroten. Oudere of mindervalide personen zullen dankzij technologie meer kunnen participeren in werk en samenleving.

De mens is de cruciale succesfactor in de wereld van Werk 4.0. Technologische transformatie, AI en robotisering staan niet gelijk met automatiseren, maar met investeren en heruitvinden. Ze zijn niet alleen een bedreiging voor menselijke banen. Ze zijn ook, en misschien zelfs vooral, een vernieuwing van menselijke rollen en functies. Naarmate de machine ons nog meer bevrijdt, komen juist menselijke eigenschappen, vermogens en rollen naar voor die machines niet aankunnen en waarvan machines afhankelijk zijn. ${ }^{26}$ Technologie kan dus omarmd worden als Well: Perspectives on Good Work and why it matters, Londen 2018.

24 Zie Eichhorst 2015.

25 Zie bijvoorbeeld J. Gonçalves \& P.S. Martins, The Effect of Self-Employment on Health: Evidence from Longitudinal Social Security Data, IZA DP 2018, nr. 11305.

26 Zie H.J. Wilson, P.R. Daugherty \& N. Morini-Bianzino, The Jobs that Artificial Intelligence will create, MIT Sloan Management Review 2017; vergelijk ManpowerGroup, Skills Revolution 2.0, 2018. 
een opportuniteit om mensen beter, efficiënter en kwalitatiever te laten werken. ${ }^{27}$ Als de toekomst van arbeid in technologie ligt, zal elke bedrijfsstrategie taken identificeren die technologie moet doen en simultaan processen ontwikkelen om die taken te koppelen aan de menselijke activiteit die ze benut.

De welvaart van een bedrijf loopt via het welzijn van de medewerkers wanneer talent, inzet, creativiteit, samenwerking en gedrag determinerend zijn. Het valt daarom te verwachten dat organisaties technologie zullen omarmen om personeelsbeleid te vermenselijken. ${ }^{28} \mathrm{Als}$ hr in het verleden mensen zo veel mogelijk als machines moest doen werken, zal hr in de toekomst mensen zo weinig mogelijk als machines laten werken. Meer en betere data betekenen meer productiviteit en minder verspilling. Technologie zal bedrijfsprocessen en -beslissingen slimmer en sneller maken. Technologie kan personeelsbeleid meer personaliseren. Aanwerven, opleiden, vormen, begeleiden en beoordelen: in alle dimensies kan technologie het personeelsbeleid verbeteren in het voordeel van zowel mens als organisatie. Gedrag, engagement en voldoening kunnen via communicatietechnologie en metadata worden gemeten en gestimuleerd.

Globaal genomen, heeft het historisch traject van eeuwen technologische innovatie altijd maar meer, betere en productievere arbeid gebracht. Er is geen reden om te verwachten dat de toekomst daarin anders wordt. Werk 4.0 is een enorme opportuniteit, niet zozeer om de werkende mens te elimineren, maar om hem te helpen in zowel de productiviteit als de kwaliteit van zijn arbeid. Meer productiviteit betekent meer inkomen en meer tijd. In het privéleven zal technologie, net zoals in het verleden, de mens bevrijden of helpen bij taken en klussen. Meer privéleven vergemakkelijkt het beroepsleven. In onze vergrijzende samenleving zullen medische technologie en zorgrobots cruciaal zijn voor het opvangen van zorgnoden. We moeten als samenleving alleen die kwaliteitsopportuniteiten ook daadwerkelijk grijpen.

Vooruitgang zal niet zonder vooruitgangsziekten zijn. We kennen stress, burnout en bore-out als fenomenen van een evolutie die arbeidsbelasting van het lichamelijke naar het geestelijke heeft verschoven. Het kwaliteitsperspectief op Werk 4.0 vergt grenzen: aan beschikbaarheid en bereikbaarheid van medewerkers, aan wie wat mag doen met data en communicatie in een organisatie, aan de interactie met nieuwe technologie wanneer die welzijnsrisico's inhoudt. Ankerpunten van de arbeidsorganisatie verschuiven: arbeidsplaats, arbeidsduur, gezag en controle evolueren en maken de arbeidscontext persoonlijker. Arbeid wordt een poreus proces: tussen verplichte arbeid en vrijwillige arbeid, tussen arbeid en vrije tijd, tussen autonomie en controle, tussen bedrijf en woning vervagen de lijntjes. Dat vraagt een nieuwe balans die arbeidsdiversiteit met arbeidskwaliteit verbindt.

Dezelfde technologie die de mens meer autonomie geeft, onderwerpt de mens ook aan meer controle en navenante psychologische druk, een fenomeen dat nu al opduikt in de platformeconomie die app-gebruikers permanent volgt. We kunnen tivity, 2017. 
ons aan nieuwe fenomenen verwachten en we zullen ermee moeten omgaan, zowel preventief als curatief, zowel regelgevend als in personeelsbeleid. Als de wisselwerking tussen mens en machine systemisch wordt, zal een regelgevend kader ontstaan om de voorwaarden daarvan te bepalen, inclusief ethische grenzen. Arbeid is en blijft een sociaal gegeven. De opkomst van intelligente machines die daarin een volwaardige plaats krijgen, zal zeker sociale vragen opleveren.

Het tijdperk van Werk 4.0 biedt ook kwaliteitsinnovatie voor wetgever, overheid en administratie. Zij kunnen technologie gebruiken om arbeid beter te reguleren en beter te organiseren. We zien daarvan al een pril begin in landen die voor de platformeconomie een erkenningskader bieden dat gebonden is aan de automatische betaling van belastingen op de transacties die via de platformen verlopen. De verzekeringen, bijdrageverplichtingen en administratieve overhead die met tewerkstelling gepaard gaan, waarvoor bedrijven nu vaak hr-diensten inhuren, is vatbaar voor digitalisering. Kwaliteitsvolle loopbanen vergen kwaliteitsvolle regulering en dito beheer, en daarvoor biedt het nieuwe technologische arbeidstijdperk grote kansen.

Arbeidsrelaties die digitaal draaien, zijn met andere woorden een grote beleidsopportuniteit. Ze kunnen zwartwerk en uitkeringsfraude elimineren. Ze garanderen volstrekte transparantie in arbeidsduur en verloning. Belastingen en sociale bijdragen kunnen instant en met nul bureaucratie worden betaald. Platformen kunnen de hele winkel van een arbeidsrelatie vlekkeloos en automatisch organiseren. Arbeidsbemiddeling kan naar een volgende dimensie worden getild. Langere en betere loopbanen, gevarieerde loopbanen met meer jobwissels, loopbanen die in elke fase vorming faciliteren, loopbanen met sociale verzekering die gaat waar de persoon gaat: het kan allemaal worden georganiseerd. Technologie kan ons langer en beter doen werken.

\subsection{Talentrecht}

Onze hoogtechnologische, geglobaliseerde kenniseconomie legt een intieme band tussen menselijk talent en economisch resultaat, een trend die ik 'menskapitalisme' heb genoemd. ${ }^{29}$ Talent is de brandstof van de hedendaagse economie, de voorspeller van loopbaantrajecten en de drijfveer voor de massale mobilisatie voor onderwijs en opleiding in 'de race tussen onderwijs en technologie'. ${ }^{30}$ En dat is slechts een begin.

De hiervoor geschetste combinatie van demografische vergrijzing en pensionerende babyboomers, hyperdiversiteit, geconcentreerde arbeidsmarktmarginalisatie en -segmentering onder jongeren makt van talent de centrale beleidsprioriteit van de toekomst. Tel daarbij de massale baantransitie en baaninnovatie die de technologische revolutie kan betekenen, en het lijkt logisch het arbeidsrecht van de toekomst fundamenteel richting talentrecht zal evolueren. Het ontwikkelen, onderhouden en vernieuwen van economisch nuttig menselijk talent dat breed de mens op de arbeidsmarkt ondersteunt, zal tot het DNA van de arbeidsregulering doordringen. 
De insteek van talentrecht heeft meerdere dimensies. Conceptueel verstrengelt hij arbeid en onderwijs. We kijken nog naar leven en werken in gescheiden chronologische fasen: school, diploma, werk, opleiding, vorming, verlof, bijscholing en dergelijke. Onze blik op talentontwikkeling is nog verzuild en verkapt. In de evolutie van arbeidsrecht naar talentrecht zal talentontwikkeling niet in gescheiden silo's maar transversaal en vermengd doorheen leven en loopbaan lopen. Arbeidsverhoudingen worden dan een onderdeel van een continu proces van scholing en vorming, waarbij andere en nieuwe partijen, nieuwe rollen, nieuwe financiering en nieuwe leerformules worden betrokken. Opleiding en vorming worden niet alleen deel van de job, maar deel van de loopbaanontwikkeling, in een perspectief van gemeenschappelijke verantwoordelijkheid.

Als talentrecht zal arbeidsrecht samenwerken met onderwijs dat meer inzet op leervermogen, cognitieve capaciteit, creativiteit, analytisch denken en weerbaarheid. Onderwijs worstelt met het dilemma dat bestaande kennis voorbestemd is om te verouderen en dat toekomstige kennis onmogelijk kan worden voorspeld. Werk 4.0 zal de omloopsnelheid van kennis vergroten. Niet zozeer technische kennis, maar het vermogen tot verandering, tot kritisch en creatief denken, tot samenwerking en tot omgaan met complexiteit is noodzakelijk. Doorlopend talent kunnen ontwikkelen en aanpassen, onder het motto van levenslang leren, is de enige strategie. Daarom zal onderwijs niet alleen inzetten op de overdracht van kennis en vaardigheden, maar ook op zogenoemde 'metavaardigheden' voor toekomstbestendig leren, die de toekomstige volwassenen zelfredzaam maken. ${ }^{31}$ Dat vergt hybride skills: een mix van technische basiskennis, cognitieve vaardigheden en persoonlijke attitudes die ons klaarstomen om een leven lang met technologie om te gaan en ermee te evolueren. ${ }^{32}$

In onderwijs en vorming zal technologie zowel kwantiteit als kwaliteit en toegankelijkheid bevorderen, zoals we dat nu al merken met online universiteiten en cursussen. Virtuele realiteit en AI zullen nog meer mensen beter en gemakkelijker onderwijs laten genieten, van de beste instellingen, aan lage kostprijs. Via technologie kan het klassieke diplomaonderwijs evolueren naar onderwijsmodules die in elke levensfase kunnen worden benut. Op die manier zal onderwijs de arbeidsmarkt doorlopend ondersteunen. Bedrijven en organisaties moeten meer selecteren op kunnen in plaats van kennen, op skills in plaats van formele diploma's. De regulering van beroepskwalificaties moet hen daarin helpen. Technologisch gepersonaliseerd personeelsbeleid zal toelaten de noden en behoeften van medewerkers preciezer op te volgen. Talentmanagement en -ontwikkeling kan zo meer op tijd en meer op maat gebeuren, wat opnieuw betrokkenheid, motivatie en welzijn zal bevorderen.

Voor bedrijven illustreert talentrecht hoe talentmanagement een strategische bedrijfsprioriteit wordt. ${ }^{33}$ De combinatie van talentschaarste en skillstransforma-

31 Zie bijvoorbeeld P.A. Kirschner, Het voorbereiden van leerlingen op (nog) niet bestaande banen, Heerlen: Open Universiteit 2017.

32 Zie ook L. Rainie \& J. Anderson, The Future of Jobs and Jobs Training, Pew Research Center 2017.

33 Zie de cijfers en trends beschreven in World Economic Forum 2016. 
tie betekent dat bedrijven nooit de sprong naar Werk 4.0 kunnen maken zonder te investeren in omscholen en bijscholen. Technologie gebruiken om productiviteit en winstgevendheid te vergroten, om repetitieve en routinetaken te elimineren, om de mens in te zetten voor meer hoogwaardige activiteiten: dat komt heus niet vanzelf. Bedrijven zullen niet alleen moeten investeren in de hardware, maar ook in de software van hun organisatie: niet alleen in technologie en machines, maar ook in mensen en in de organisatie van hun samenwerking. Technologische innovatie zal slechts renderen wanneer ze benut wordt door innovatie van arbeid, personeel en arbeidsorganisatie. Dat vergt een echte bedrijfsstrategie om technologie aan talent te koppelen. ${ }^{34}$

Voor de samenleving is talentrecht essentieel voor inclusie, kansen en opwaartse mobiliteit. Werk 4.0 is een gigantische opportuniteit voor meer talentinclusie door lagere arbeidsbarrières, meer arbeidskeuze en meer arbeidsdiversiteit. Maar het is ook een risico voor talenterosie. Er zullen verliezers zijn. Aan de top kunnen winnaars nog meer winnen doordat hun talent en skills nog productiever en op nog grotere schaal kunnen worden ingezet. Maar elders zijn gevaren reëel. In het midden zou cognitieve AI intellectuele routinetaken kunnen overnemen, zoals schrijven, communiceren, vervoeren, aankopen, boekhouden, contractbeheer, medische diagnoses en kantooradministratie. Onderaan zouden robots menselijke handelingen en interactie kunnen overnemen in laagproductieve banen, in productie, in distributie, in zorg en in persoonlijke diensten.

Technologie is dus niet talentneutraal en het lijkt logisch dat de megatrends achter Werk 4.0 de al vermelde arbeidspolarisatie - de combinatie van een sprintende top, een verdwijnend midden en een stagnerende bodem - kunnen versterken. De hybride skills die het huwelijk tussen mens en technologie kunnen smeden, worden zeer ongelijk verworven, vroeg in het gezin en aansluitend in het onderwijs. Als we die talentongelijkheid niet verminderen, zullen veranderende banenstructuren de resulterende arbeidsongelijkheid doen toenemen. ${ }^{35}$ We zullen samenlevingsbreed moeten mobiliseren voor een talentshift om verliezers tot winnaars te maken. Dat kan door talentontwikkeling te mainstreamen als een kernwaarde van het sociaal beleid, met technieken zoals opleidingscheques, skillsgaranties, individuele leerrekeningen, subsidies en belastingvoordelen. ${ }^{36}$ Daarin krijgt het arbeidsrecht een centrale en verbindende plaats.

De verre toekomst van talent mag dan al een vraagteken zijn, maar datamodellen kunnen de baantransities en talentnoden van Werk 4.0 modelleren op middellange termijn. Dergelijke modellen suggereren golven van arbeidsvernieling en -vernieuwing die verschillende sectoren en beroepsgroepen op verschillende tijdstippen en met verschillende impact treffen. ${ }^{37}$ Op basis daarvan kunnen beleids-

34 Zie bijvoorbeeld E. Shook \& M. Knickrehm, Reworking the revolution, Accenture Strategy 2018.

35 Zie European Parliamentary Research Service 2018; Lawrence e.a. 2017.

36 Zie bijvoorbeeld ILO Global Commission on the Future of Work, Skills policies and systems for a future workforce, 2018.

37 Zie bijvoorbeeld H. Bakhshi e.a., The Future of Skills: Employment in 2030, Londen: Pearson and Nesta 2017; McKinsey, Shaping the future of work in Europe's 9 digital front-runner countries, 2017; PwC, Will robots really steal our jobs?, 2018; World Economic Forum, Towards a Reskilling Revolution: A Future of Jobs for All, 2018. 
makers met voldoende zekerheid prioriteiten definiëren en paden voor toekomstige baantransities voorbereiden. Noem het preventief doelgroepenbeleid in talentontwikkeling. Het motto van talentrecht hoeft dus geen holle slogan te zijn. We kunnen zowel de brede talentontwikkeling voor de lange termijn als de concrete talenttransitie voor de kortere termijn organiseren. De omslag naar talentrecht kan dus veel latere arbeidsmarktproblemen helpen voorkomen. We moeten alleen durven kiezen voor preventie in plaats van te wachten tot transitieproblemen zich effectief op de arbeidsmarkt aandienen.

\subsection{Activiteitsrecht}

Activering 2.0, transversale loopbaanrechten, preventief doelgroepenbeleid en een algemene focus op talentontwikkeling zullen zeker tewerkstellingsrisico's ondervangen en verminderen, maar kunnen die niet volledig elimineren. Er zal een donkere kant blijven aan de arbeidsrealiteit van Werk 4.0. Hoe moeten we als samenleving daarmee omgaan? De conservatieve pavlovreflex is arbeidspolarisatie bestrijden door haar te verbieden. Klassiek begrenzend arbeidsrecht, aangepast aan de wereld van Werk 4.0. Nieuwe beperkingen voor arbeidsflexibiliteit, voor korte contracten, voor oproepcontracten, voor arbeidsduurversnippering, voor 'just in time' opdrachten, tot en met het verbieden van bepaalde arbeidsvormen of commerciële platformen. ${ }^{38}$

Een andere optie is de beschermingsverschillen tussen reguliere contracten en atypische arbeid afbouwen. Arbeidsrecht evolueert dan naar een breder activiteitsrecht dat bescherming biedt, ongeacht het onderliggende arbeidsrechtelijk statuut. De lat gelijk leggen klinkt aantrekkelijk, maar waar leggen we de lat dan? In het vorenstaande is gepleit voor algemene activeringsrechten en loopbaanrechten die geen onderscheid maken tussen arbeidsstatuten. Dat is een fundamentele kentering ten aanzien van de courante segmentering, die ik hierna nog verder doortrek in een persoonsrechtelijke benadering. Ten gronde is symbiose van arbeidsstatuten wenselijk, op voorwaarde dat ze de brede positieve dynamiek van Werk 4.0 niet artificieel tegenhoudt. Dat betekent dat de lat gelijk komt te liggen, niet alleen door nieuwe bescherming voor nieuwe arbeidsvormen, maar ook doordat hij voor de insiders in vaste contracten wat lager wordt gelegd.

In essentie moet het arbeidsrecht als activiteitsrecht de arbeidsflexibiliteit tot in de kern van de arbeidsrelatie omarmen. Vooral in arbeidsduurregulering is dat al verworven. Maar Werk 4.0 vereist de accommodatie van arbeidsdiversiteit in een kader dat de klassieke arbeidsovereenkomst overstijgt. Dat kan alleen door van de arbeidsovereenkomst een overeenkomst te maken die meerdere en veranderende partijen aankan. Vandaar de vermelde referentie aan het model van uitzendarbeid en het voorstel van de loopbaanrekening. Uitzendarbeid is weinig meer dan de capaciteit van een werknemer flexibel over meerdere werkgevers gebruiken. De veralgemening daarvan zou de zogeheten co-sourcing van werknemers door verschillende werkgevers mogelijk maken. Dat combineert grotere arbeidsflexibiliteit met het behoud van de arbeidsovereenkomst als statuut. 
Een variant is werknemerspooling, zoals bekend in Oostenrijk, Frankrijk, Duitsland en de VS. Pooling biedt een wettelijk kader om werknemers voor meerdere organisaties en bedrijven te laten werken, inspelend op complementaire noden en ligging. Bij pooling leidt de economische noodzaak van flexibiliteit evenmin tot een versnippering van arbeidsrelaties. Pooling en co-sourcing kunnen zelfs als externe dienstverlening worden opgezet, zodat ze, net als uitzendarbeid, de participerende gebruikers ontlasten van de coördinatie en de participerende werknemers verzekeren van bescherming. Risico's van misbruik moeten onder Werk 4.0 niet meer leiden tot verboden, maar tot slimme regulering met waterdichte digitale opvolging.

Hoe fijn en gesofisticeerd arbeidsregulering, arbeidsbescherming, arbeidsondersteuning, talentontwikkeling en activering ook mogen zijn, er zullen verliezers door de mazen van het net glippen. Onze globale groei van activiteit en tewerkstelling verbergt al een zogenoemd 'precariaat' van groepen met weinig tot geen loopbaanperspectief. De disruptieve impact van Werk 4.0 op economie en bedrijf, zijn ongelijke distributieve effecten op arbeidskansen en loopbanen, dwingen ons ook daarin tot beleidsinnovatie. Werkloosheid en bijstand zijn de terugvalbasis voor de ongelukkigen van de arbeidsmarkt. We kunnen beide verbinden en versterken in een voluntaristische aanpak die elders als werkverzekering is verdedigd. $^{39}$

De werkverzekering combineert de inkomensgarantie van werkloosheidsverzekering en sociale bijstand met een werkgarantie voor iedereen, tegen een gemeenschappelijke achtergrond van doorgedreven activering. In een eerste fase blijven werkloosheidsuitkeringen doorslaggevend en genereus, lang genoeg en hoog genoeg voor kwalitatieve baantransitie. Daarna volgt een periode van communicerende vaten: enerzijds degressieve uitkeringen die dalen met de duurtijd van inactiviteit, anderzijds progressieve investeringen in activering. Maatwerk is daarbij cruciaal. In het ideale scenario kunnen het tempo, de omvang en de modaliteiten van uitkeringen en investeringen aangepast worden aan de noden en behoeften van de persoon en van de relevante arbeidsmarktrealiteit. Dat vergt uiteraard de nodige verfijning in dienstverlening en arbeidsmarktdata.

Er zullen uiteindelijk altijd werklozen zijn die geen werk vinden. Indien de uitstroom naar de reguliere arbeidsmarkt niet lukt na een bepaalde periode, opnieuw te beoordelen in het licht van alle relevante parameters, wordt overgestapt naar een regime van georganiseerde tewerkstelling en dienstverlening aan de gemeenschap. De betrokken personen hebben weliswaar geen regulier werk, maar ze doen een maatschappelijk zinvolle activiteit in ruil voor een inkomen. De insteek van activiteitsrecht verbindt het arbeidsrecht met activerende bijstand en transformeert het finaal in een recht op arbeid.

De werkverzekering trekt de activeringslogica door tot haar ultieme consequentie waarin de activerende overheid zelf de activiteit aanbrengt. Ze onderstreept de wisselwerking tussen rechten en plichten, die het cement vormt van de sociale zekerheid in onze samenleving. Uitkeringsfraude verdwijnt. Bovenal garandeert de werkverzekering dat elke werkwillige actief blijft. Er gaat geen talent verloren. 
Mits goed beheerd zal de werkverzekering ook talent onderhouden dat kan terugvloeien naar gewone tewerkstelling. Activering onderhoudt dan reactiveringspotentieel.

\section{Het einde van arbeidsrecht}

\subsection{Het einde van arbeid}

Sinds twee onderzoekers van de universiteit van Oxford vijf jaar geleden voorspelden dat bijna de helft van alle Amerikaanse werkgelegenheid zou zijn bedreigd door computers en robots, hangt er een sfeer van apocalyps over de toekomst van werk. ${ }^{40}$ Pessimisten, onder wie enkele ondernemersiconen van de interneteconomie, denken dat artificiële intelligentie en robotica uiteindelijk de mensheid grotendeels werkloos zullen maken. De samenleving zou dan uiteenvallen in drie delen: de elite die de computers zegt wat te doen, de minderheid die door computers gezegd wordt wat te doen, en de meerderheid die door computers wordt vervangen.

Rampzalige toekomstprojecties over banendestructie trekken de banenstructuur van de huidige economie uit elkaar in taakprofielen en kruisen die met de voortrazende rekencapaciteit van computers, robots en AI. Het vergt dan geen grote verbeelding om te veronderstellen dat veel taken die vandaag nog onaantastbaar zijn, morgen wellicht door computers kunnen worden gedaan en wellicht nog beter ook. Computers zullen dan medische diagnoses stellen, juridische documenten afleveren, teksten vertalen, lesgeven, vliegtuigen en tankers besturen of nieuws verslaan: allemaal voorbeelden waar de computerisering al begonnen is. Als daarenboven robots op het kantelpunt van de grote doorbraak staan, zodat zorg, distributie, vrachtafhandeling en wat overschiet van industriële productie een nieuwe golf van automatisering wacht, is de apocalyps nabij.

Maar banen zijn veel meer dan taken. Het is niet omdat bepaalde taken door machines worden overgenomen dat de rest en de mens verdwijnen. Wel integendeel: de eliminatie van routinetaken is juist de springplank om de mens te complementeren richting betere en productievere banen waarin menselijke talenten nog meer naar voren komen, zoals hiervoor is beklemtoond. Het einde van taken is niet het einde van banen, noch het einde van arbeid. Projecties die kijken naar banen in plaats van taken zijn veel rooskleuriger over de verwachte arbeidsvernietiging, maar voorspellen wel dat baanverandering zal versnellen en veralgemenen. ${ }^{41}$ Overigens evolueert Werk 4.0 weg van banen en beroepen, naar opdrachten, netwerken, organisatie en samenwerking, meer collaboratief en minder

40 C.B. Frey \& M.A. Osborne, The future of employment: how susceptible jobs are to computerisation?, University of Oxford 2013.

41 Zie bijvoorbeeld M. Arntz, T. Gregory \& U. Zierahn, The Risk of Automation for Jobs in OECD Countries: A Comparative Analysis (OECD Social, Employment and Migration Working Papers, nr. 189), Parijs: OECD Publishing; European Commission, Analysis of the impact of robotic systems on employment in the European Union, Luxemburg: Publications Office of the European Union 2016; L. Nedelkoska \& G. Quintini, Automation, skills use and training; OECD, Automation and independent work in a Digital Economy, OECD Policy Briefs on the Future of Work, 2016. 
gestructureerd. De statische projectie van technologisch vermogen op bestaande takenprofielen in gekende beroepen kijkt naar de toekomst van werk door de bril van het verleden. Niet arbeid als zodanig, maar vaste banen en beroepen staan op de wip.

Baanpessimisme is daarenboven eenzijdig. Er is ook het optimisme van nieuwe technologiebanen en meer productiviteit. Dat is precies het voormelde patroon van kapitalistische innovatie door creatieve destructie. Studies die zowel de destructie als de creatie van Werk 4.0 begroten, landen niet bij totale arbeidsvernietiging, maar integendeel bij een batig saldo van meer totale werkgelegenheid. ${ }^{42}$ Daarenboven kan geen enkel model de factor keuze berekenen. Het is niet omdat technologie bepaalde menselijke taken kan overnemen dat het ook zal gebeuren. Daarvoor moeten bedrijven investeren. Daarvoor moet investeren voldoende renderen. Daarvoor moeten bedrijfsorganisatie en de interactie tussen mens en machine evolueren. Daarvoor moeten werknemers willen en kunnen meegaan. Daarvoor moet arbeidsregulering meedoen. Allemaal factoren die de technologische transformatie absoluut zullen afremmen en sturen.

Zwartgallige baanpessimisten verwachten de grootschalige arbeidsdestructie trouwens pas tegen het midden van de 21ste eeuw, in een lang en onvoorspelbaar traject van meerdere decennia. Zelfs de meest kwetsbare beroepen, zoals kassierster of bestuurder, zullen maar traag en geleidelijk leeglopen, met veel ruimte voor aanpassing, reconversie en nieuwe kansen. Het veronderstelde 'einde van arbeid' is dus sowieso verre van nabij, het is de futurologie van het ongekende onbekende. Die voegt weinig toe aan het gekende onbekende, namelijk dat de technologische transformatie arbeidsregulering verplicht om de loopbaan als centraal paradigma te kiezen. Zelfs als de pessimisten gelijk zouden hebben, blijven activeringsrecht, loopbaanrecht, arbeidskwaliteitsrecht en talentrecht de collectieve missie van het vernieuwde arbeidsrecht in de voorzienbare toekomst.

En toch blijft een wereld zonder arbeid sommigen fascineren en inspireren tot een complete herijking van de welvaartsstaat via een universeel basisinkomen (UBI) dat iedereen inkomen zonder arbeid garandeert. Dit is niet de plaats voor de doorlichting van een idee dat al een half millennium meegaat en dat in volwassen vorm het DNA van persoonlijke verantwoordelijkheid, samenleving, ongelijkheid, sociale bescherming en economie diepgaand verandert. ${ }^{43}$ Ons perspectief is de wereld van Werk 4.0. Om die wereld een kans op succes te gunnen is UBI geen oplossing maar een probleem.

Een algemeen en onvoorwaardelijk basisinkomen betekent een gigantische budgettaire kost. Elke euro die naar basisinkomen gaat, kan niet gaan naar investeren, activeren, loopbaanontwikkeling, opleiding, vorming, onderwijs en zo verder. Terwijl Werk 4.0 samenlevingsbreed mobilisatie voor activiteit en participatie vergt, zou UBI vele miljarden gratis geld uitgeven. Aan dat geld is daarenboven geen enkele formele activering gekoppeld. Onvoorwaardelijke uitkeringen in de

42 Zie McKinsey, Shaping the future of work in Europe's 9 digital front-runner countries, 2017.

43 Zie M. De Vos \& S. Ghiotto, Basisinkomen tussen droom en werkelijkheid, Brussel: Itinera Institute en Skribis 2017. 
context van grote economische transities en herstructureringen dreigen eerder talentmobilisatie en baanverandering af te remmen dan ertoe bij te dragen.

Veel belangrijker dan de kwantitatieve calculus van verloren en nieuwe jobs is te begrijpen wat achter de dynamiek schuilt. Het gaat niet over banenverlies, maar over de aard van de banen die blijven of bijkomen. We hebben gezien hoe Werk 4.0 jobkwaliteit kan veranderen. Bedreigde banen zitten vooral in het middendeel waar routinetaken, in toenemende mate ook cognitieve, door technologie worden overgenomen. Onderaan blijven laagbetaalde banen die menselijke interactie en handelingen vergen onaangeroerd en dus laagproductief. Bovenaan, waar technologie, globalisering en talent elkaar versterken, is het feest. Wie de zandloper van polariserende arbeid en toenemende arbeidsongelijkheid wil aanpakken, moet geen cheques uitdelen, maar breed in kansenbeleid investeren. ${ }^{44}$ Een universeel basisinkomen is mijns inziens het verkeerde idee, op de verkeerde plaats, op het verkeerde moment.

Voor wie toch wil filosoferen over een wereld waarin arbeid uitsterft, zijn er genoeg alternatieven die minder tot dat uitsterven bijdragen. ${ }^{45}$ We kunnen het beproefde recept van een negatieve inkomstenbelasting verbreden: die stimuleert en beloont arbeid en steunt alleen diegenen die het nodig hebben. We kunnen de voormelde werkverzekering aanwenden om werklozen toch nuttig en zinvol aan de samenleving te laten bijdragen: een baan zonder arbeid in plaats van inkomen zonder arbeid. We kunnen een betaalmodel ontwikkelen voor maatschappelijk nuttige maar niet-economische arbeid, zoals buurtveiligheid, thuiszorg en huishoudelijk werk. We kunnen de data-economie die mensen zonder arbeid zet, aan diezelfde mensen laten betalen voor de persoonsdata waarop de data-economie draait en die ze nu gratis online capteert. We kunnen tanende lonen opkrikken door werknemers minder voor arbeid en meer uit bedrijfswinsten te vergoeden. We kunnen zelfs arbeidsduurverdeling overwegen, al zal die spontaan volgen uit hogere productiviteit en meer gepersonaliseerde arbeid.

\subsection{Het einde van de arbeidsrelatie}

Het einde van de arbeidende mens is al vaak voorspeld, maar (nog) nooit uitgekomen. Het einde van de klassieke arbeidsrelatie is daarentegen waarneembaar op het internet.

Digitale verbindingsplatformen zoals Uber, Taskrabbit, Fiverr of Helpling verbinden klanten met professionals voor ad-hocdienstverlening op vraag. Ze zijn een alternatief voor prospectie en aanwerving. Op digitale marktplaatsen, crowdsourcing of outsourcing sites, zoals Upwork, Amazon Mechanical Turk, AppJobber en Airtasker, kunnen gebruikers specifieke en gespecialiseerde taken en opdrachten als micro-jobs uitbesteden aan derden. Zij zijn een alternatief voor arbeidsrelaties of aanneming. Sites voor crowdworking of crowdfunding, zoals Crowdtap, Kickstarter en Indiegogo, faciliteren het samenwerken van deelnemers aan gemeenschappelijke projecten. Ze zijn een alternatief voor bedrijfsorganisatie en personeels-

45 Zie ook D.M. West, What happens if robots take jobs? The impact of emerging technologies on employment and public policy, Brookings 2015. 
groepen. Via digitale deelplatformen of sharing sites, zoals Streetbank, Peerby of Nextdoor, kunnen goederen en infrastructuur collectief worden gebruikt, al dan niet tegen betaling. Ze zijn een alternatief voor eigendom en arbeidsmiddelen. Via communicatie- en toolplatformen zoals Facebook, WeChat, Slack, Trello of CoSchedule kunnen professionals communiceren, vergaderen, organiseren en diverse zakentools gebruiken. Ze zijn een projectalternatief voor management en bedrijfsstructuren. Via co-working sites zoals WeWork, Hubble of Pickspace kunnen professionals van diverse pluimage werkruimtes en omgevingen benutten die zowel hun eigen activiteit als ad-hocsamenwerking bevorderen. Ze zijn een alternatief voor bedrijfsorganisatie en infrastructuur. Via de gekende online webwinkels en de nieuwe bestel- en leveringsplatformen zoals Postmates, Deliveroo, UberEATS, of Foodora kunnen producten en maaltijden aan huis worden geleverd. Ze bevrijden de consument van reistijd en kleven op klassieke economische activiteiten een laag van transportdiensten die online worden georganiseerd.

Deze en andere varianten van wat gemeenzaam de 'platformeconomie' kan worden genoemd, zijn dus de wereld van arbeid en arbeidsrecht aan het veroveren. ${ }^{46}$ Arbeidsrelaties worden er ofwel overbodig, ofwel versneden, ofwel gedigitaliseerd. Overbodig omdat een onderneming kan tewerkstellen zonder werkgever te zijn en omdat werkers kunnen werken zonder werknemer te worden. Ondernemingen evolueren van statische hiërarchieën naar flexibele projectorganisaties, arbeidskracht wordt in essentie verhandelbaar over het internet. Versneden omdat de economische samenwerking die de arbeidsrelatie uiteindelijk is, wordt verkapt in blokken, taken en micro-opdrachten die instant aflopen. Gedigitaliseerd omdat de huishouding van een economische samenwerking, waarvoor het arbeidsrecht ten gronde bestaat, wordt overgenomen door transacties en algoritmes die de juridische infrastructuur vervangen door automatisch management.

In het beste geval kunnen personen via platformen vrij, overal, met en voor iedereen werken en samenwerken, kortom hun eigen baas zijn en toch volwaardig aan grootschalige activiteiten deelnemen. Voor bedrijven kunnen platformen expertise en capaciteit genereren zonder de last en kost van bedrijfs- en personeelsorganisatie, wat algemeen productiviteitsgroei kan bevorderen. In het slechtste geval doen internet en digitalisering voor de diensteneconomie wat het fordisme en taylorisme voor de industriële economie deden: arbeid herleiden tot taken en koopwaar, mensen herleiden tot schakels, kosten besparen voor marktspelers en afwentelen op mensen. ${ }^{47}$

In elk geval doorkruist de platformeconomie grondig de klassieke configuratie van arbeid en tewerkstelling. Ze vervaagt kwalificaties, taken en rollen. Ze introduceert ongekende dimensies van flexibiliteit, ten voordele van onafhankelijkheid, maar ten nadele van zekerheid. Ze verlegt de grens tussen werknemers en zelfstandigen, tussen betaald en onbetaald werk, tussen werk en niet-economi-

46 Zie bijvoorbeeld J. Landmann \& S. Heumann, Auf dem Weg zum Arbeitsmarkt 4.0? Mögliche Auswirkungen der Digitalisierung auf Arbeit und Beschäftigung in Deutschland bis 2030, Berlijn: Bertelsmann-Stiftung/Stiftung neue Verantwortung 2016.

47 R. Berins Collier, V.B. Dubal \& C. Carter, Labour Platforms and Gig Work: The Failure to Regulate, IRLE Working Paper nr. 106-17; K.V.W. Stone, From Widgets to Digits: Employment Regulation for the Changing Workplace, Cambridge University Press 2004. 
sche activiteit, tussen werkers en bedrijven, en tussen werkers en consumenten. Platformen zetten turbo's op de trend van 'freelancers', zowel aan de vraagzijde als aan de aanbodzijde van de arbeidsrekening. Ze verminderen kosten voor ondernemingen en consumenten, maar verminderen ook de beloning en de sociale bescherming van de platformwerkers. Voor prestaties die geen fysieke samenwerking vergen, verbinden platformen de hele wereld. Bedrijven of gebruikers uit rijke landen kunnen er spotgoedkoop arbeidspotentieel uit armere landen aanboren: digitale globalisering voor de diensteneconomie.

In de platformeconomie liggen de kiemen van een grootschalige digitalisering van economische activiteit. Platformen fungeren als interfaces die de bouwstenen van economische samenwerking afbouwen. Gebruikers sturen er de dienstverleners: consumenten worden producenten, louter door te consumeren. Arbeid, arbeidsrecht en arbeidsgrenzen verdwijnen grotendeels naar de geschiedenisboeken. Als overmorgen productie en distributie door robots zouden gebeuren, transport door zelfsturende machines en diensten door AI en blockchain, kunnen platformen de laatste menselijke tussenschakels elimineren. De platformeconomie kan de weg plaveien naar werken zonder werknemers en zonder werkgevers. Geen wonder dat ze de wereld van arbeidsjuristen en arbeidsmarktexperten in vuur en vlam zet, met de nodige rampliteratuur tot gevolg.

Mijn belangrijkste boodschap is om kalm te blijven. Alle beschikbare data demonstreren dat voorlopig slechts een kleine minderheid van de beroepsbevolking actief is in de platformeconomie, hooguit luttele percenten in de meest ontwikkelde markten. ${ }^{48}$ De geografie van platformwerk is vooral grootstedelijk. Bovendien suggereren steekproeven dat slechts een kleine minderheid op het platform haar hoofdactiviteit organiseert. De grote meerderheid werkt er slechts sporadisch of deeltijds, voor korte tijd en vooral gemotiveerd door de flexibiliteit en de bijverdienste. ${ }^{49}$ In die optiek mobiliseren platformen eerder arbeidspotentieel dat anders niet economisch benut wordt dan dat ze werknemers en bedrijven vervangen door platformrelaties. Ze verlagen ook de toegangsdrempel tot arbeidsparticipatie, wat goed nieuws is voor samenlevingen met hardnekkig gemarginaliseerde minderheden.

Voor arbeidsjuristen is het juridisch statuut van de platformwerker een echte kopbreker. Al decennialang groeien de werelden van ondergeschikte en zelfstandige arbeid naar elkaar toe. De megatrends waarmee we deze bijdrage zijn begonnen, maken veel werknemers in loondienst nog meer zelfstandig en veel zelfstandigen nog meer afhankelijk. De platformeconomie is daarvan de overtreffende trap. Aan de ene kant overheerst de vrijheid en autonomie van samenwerking 'op vraag' en via een platform dat alleen als medium functioneert. Aan de andere kant vergt en organiseert het platform betrouwbaarheid, kwaliteit, resultaat, conformiteit en evaluaties. De interpretatie van de gezagsverhouding die in zowat alle

48 Zie bijvoorbeeld het overzicht in Eurofound, Non-standard forms of employment: Recent trends and future prospects, Dublin: Eurofound, 2017; J.V. Hall \& A.B. Krueger, An Analysis of the Labor Market for Uber Driver-Partners in the United States, NBER WP 2016, 22843; U. Huws e.a., Work in the European Gig Economy, Brussel: FEPS 2018; K. Lepanjuuri, R. Wishart \& P. Cornick, The characteristics of those in the gig economy, BEIS Research Paper 2018/2. 
jurisdicties op een mozaïek van feitelijke en organisatorische aanwijzingen steunt, kan zo alle kanten uit. ${ }^{50}$ Dat is op zijn minst onwenselijk.

Als de platformeconomie daadwerkelijk mainstream zou worden en een substantieel aandeel van het arbeidsvolume in de economie zou claimen, staan we voor een systemisch probleem. Ofwel zal een deel van de beroepsbevolking zijn loopbaan zien verdampen in een web van losse, onzekere en vaak weinig betaalde opdrachten. Ofwel zullen de platformbedrijven en hun zakenmodel veranderen en betere arbeidsvoorwaarden bieden, wat ze tot op heden commercieel niet aankunnen. Ofwel zien we de technologie steeds verder de menselijke factor vervangen door machines, bijvoorbeeld bij transport of in het personenvervoer.

De verleiding is groot om naar regulering te grijpen. Een aparte platformregulering met politieke begrenzing, een middenstatuut tussen werknemer en zelfstandige, of een selectief verbod dat platformen aan banden legt: dat zijn de varianten die bepleit worden en die in sommige landen al werkelijkheid zijn geworden. ${ }^{51}$ Het is een gemakkelijke en redelijk arbitraire weg. Maar het is niet de weg naar een duurzame en billijke toekomst van het arbeidsrecht. Platformen moeten niet tot een kunstmatig afgelijnde kavel van de economie worden herleid. Dat ondermijnt hun potentieel voor innovatie, productiviteit, inclusie en participatie. Dat duwt platformwerkers in een minderwaardige arbeidspositie met weinig doorgroeimogelijkheid. Plaats een nieuwe categorie van 'onafhankelijke werknemers' tussen klassieke werknemers en zelfstandigen en je vermenigvuldigt kwalificatievragen: wie zijn dan 'onafhankelijke werknemers', welke bestaande werknemers en welke bestaande zelfstandigen zijn voortaan 'onafhankelijke werknemers', en hoe zal het klassieke onderscheid tussen de gewone werknemers en zelfstandigen veranderen? In plaats van één grijze zone heb je er vier.

De casus van de platformeconomie confronteert ons met de noodzaak om fundamenteel over het juridische kader voor de economisch actieve mens te reflecteren. Als het waar is dat de arbeidsrelatie uitsterft, dan rest er alleen maar de loopbaan als ankerpunt. In elk geval staat Werk 4.0 voor variatie, fluïditeit en diversiteit van arbeid, waardoor statuutgrenzen zowel wankel als problematisch zijn. Wankel omdat grenzen vervagen, problematisch omdat statuutverschillen loopbaanobstakels vormen. De noodzaak om transversaal niet de individuele arbeidsrelatie maar wel de loopbaan voorop te stellen, dwingt ons richting een juridisch kader van gemeenschappelijke loopbaanrechten ongeacht de individuele arbeidsrelatie. Het perspectief van de loopbaan vergt persoonlijke en draagbare rechten die door alle variaties van baan, loopbaan en contractspartijen kunnen worden gevoed. Als de baanvariatie toeneemt zonder dat de statuutvariatie afneemt, zullen we de ontwikkeling van loopbanen en de benutting van menselijk talent op grote schaal fnuiken. We moeten evolueren naar een gemeenschappelijke sokkel van persoonlijke rechten ongeacht het onderliggende statuut. Dat is de teneur van de rechts-

50 Zie bijvoorbeeld B. Means \& J.A. Seiner, Navigating the Uber Economy, UC Davis L. Rev. 2016.

51 Zie bijvoorbeeld S.D. Harris \& A.B Krueger, A Proposal for Modernizing Labor Laws for TwentyFirst-Century Work: The 'Independent Worker', Brookings: The Hamilton Project 2015; ILO 2017, p. 14-15. 
ontwikkelingen die ik in het vorenstaande als de toekomst van arbeidsrecht heb verdedigd.

Bijvoorbeeld voor acteurs en kunstenaars bestaan al mechanismen die sociale voordelen opbouwen over alle ups en downs van wat intrinsiek een wisselend projectbestaan is. ${ }^{52}$ Als we allemaal projectwerkers zouden worden, lijkt de marcheerrichting dus duidelijk. Dezelfde internettechnologie die arbeid in projectschijfjes versnijdt, kan trouwens sociale rechten vlekkeloos op persoonlijke projecten laten aansluiten, zonder veel overhead of transactiekosten voor de betrokken partijen. De platformspelers en de verzekeringssector experimenteren al met formules die ad-hocverzekering geven voor ad-hocleveringen en -diensten. ${ }^{53} \mathrm{Hr}$-dienstverleners en coöperaties bieden al digitale tools die freelancers toelaten zelf hun loopbaan te bemeesteren, inclusief sociale bescherming op ad-hocbasis bij elke ad-hocopdracht. ${ }^{54}$ We zien de toekomst van arbeidsrecht al voor onze ogen evolueren naar een persoonsrecht dat als een maatpak de activiteiten van de economisch actieve persoon volgt en ondersteunt.

\subsection{Persoonsrecht}

Persoonsrecht betekent een uniform kader voor persoonlijke economische activiteit, ongeacht de partijen en ongeacht de demarcatielijnen tussen sociaaljuridische statuten. Wat er in dat kader komt, is een politieke keuze en kan evolueren. Naarmate het kader opvult, vervagen de demarcatielijnen verder. Naast activering, loopbaan, talentontwikkeling en arbeidskwaliteit zullen arbeidsvoorwaarden voorspelbaar op de radar komen. Als arbeid alle statuten overstijgt, als werknemers autonome economische agenten worden, zijn arbeidsvoorwaarden wezenlijk economische reglementering. De regeling van veiligheid, aansprakelijkheid, verzekering, tot en met prijszetting: dat is allemaal al vertrouwd terrein voor het economisch recht.

Vanuit persoonsrechtelijk perspectief vallen dergelijke thema's samen met de arbeidspositie van de werkende persoon en vinden ze daarin een politieke legitimiteit. De platformeconomie kent al voorschriften over verzekeringen en discussie over prijszetting. In essentie gaat het respectievelijk om sociale zekerheid en minimumloon, maar voor een andere categorie dan werknemers. Trek dat door en je beseft dat persoonsrecht uiteindelijk niet veel van arbeidsrecht hoeft te verschillen. Anders gezegd: het vervagen van arbeidsrechtelijke statuten impliceert een toenadering tussen mens en onderneming als bron van economische activiteit en zal ook in het economisch recht tot nieuwe identificatievragen leiden. Tel daarbij de digitale deconstructie van het contract als juridisch vehikel voor samenwerking en Werk 4.0 is de spreekwoordelijke staart die de hond laat kwispelen. ${ }^{55}$

52 Zie bijvoorbeeld D. Rolf, S. Clark \& C. Watterson Bryant, Portable Benefits in the 21st Century, The Aspen Institute 2016.

53 Zie het overzicht in The Economist, How insurance policies are being adapted to freelance working, 7 april 2018.

54 Zie bijvoorbeeld YOSS van de Adecco Group en de Smart.be coöperatieve.

55 Zie bijvoorbeeld F. Seghezzi \& M. Tiraboschi, Italy's Industry 4.0 Plan: An Analysis from a Labour Law Perspective, E-Journal of International and Comparative Labour Studies 2018. 
Persoonsrecht verlegt de focus naar de persoon, persoonlijke keuze, persoonlijk talent en persoonlijke loopbaan. Persoonsrecht gaat voor een gelijk raamwerk van rechten en plichten, maar voor de ongelijke, persoonlijke invulling daarvan. Het laat arbeidsrecht evolueren naar regelgeving die een brede biotoop van activiteit kan organiseren en faciliteren, met ondersteuning van persoonlijke keuze, verantwoordelijkheid en diversiteit, en met een gemene sokkel van minimale bescherming.

Persoonsrecht betekent arbeidsrecht dat meer is dan alleen het recht voor menselijke interacties in de werkomgeving. Het zal ook de interactie reguleren tussen mens en machine en tussen machine en mens. De intieme complementariteit van mens en machine wordt een centraal thema onder Werk 4.0. Met de persoon als kernwaarde zal arbeidsrecht daarin de lijnen kunnen uitzetten, ethisch, juridisch en organisatorisch, kwantitatief en kwalitatief.

Persoonsrecht neemt de mens als draaischijf voor Werk 4.0. In die optiek neigt persoonsrecht naar een 'mensenrechtelijke' insteek, maar met een cruciale inhoudelijke switch. De bestaande sociaaljuridische mensenrechten willen van klassieke arbeidsbescherming fundamentele rechten maken. Ze verstenen het statische arbeidsrecht van weleer, met zijn beschermende focus op de baan en zijn verplichtingen voor de werkgever. Persoonsrecht verenigt onder één noemer de heroriëntering van arbeidsrecht en arbeidsorganisatie richting activerend investeren, loopbaan, talent en arbeidskwaliteit. Persoonsrecht staat voor de dynamische loopbaanbenadering, met andere rechten en plichten, met meer persoonlijke verantwoordelijkheid en met meerdere partijen en actoren.

Persoonsrecht kan arbeidsrecht deels transnationaal maken. De klassieke arbeidsbescherming en haar band met de sociale bescherming in de welvaartsstaat vormen een bescherming op maat van de natiestaat. Daarmee is arbeidsrecht ofwel een belemmering voor internationale welvaartsgroei, ofwel een slachtoffer, inclusief misbruiken en fraude. Nationaal arbeidsrecht en internationale economie combineren moeilijk. Die combinatie zal alleen maar toenemen als de globalisering verderzet en het internet alle staatsgrenzen overstijgt. Bijvoorbeeld de voormelde techniek van de geïndividualiseerde activiteit- of loopbaanrekening kan het bindmiddel zijn waarmee een internationale diversiteit van arbeidsrechten en sociale voordelen kan draaien op een gemeenschappelijke sokkel met grote transparantie en controle voor het werkende individu. Door de persoon als ankerpunt te nemen zal daarmee ook een hefboom worden gemaakt die verwachtingen en eisen bij onderhandelingen en contractafspraken zal sturen. Zo ontstaat 'bottom-up' harmonisering.

Persoonsrecht verbindt arbeidsrecht structureel en principieel met andere rechtsdomeinen die de mens en menselijke ontwikkeling centraal plaatsen, zoals onderwijs, beroepsvorming, huisvesting, bijstand, gezinsbeleid en jeugdbeleid. Het integreert arbeidsrecht in een holistisch continuüm van kansenbeleid dat investeert in de ontwikkeling van menselijk potentieel. Talentbeleid is niet langer versneden in levensfasen en bevoegdheidssferen. Persoonsrecht trekt in de arbeidsrechtelijke sfeer actoren, rechten en verplichtingen die er traditioneel buiten staan, met een overkoepelende talentmissie. Dat impliceert een coördinatie van beleidsbevoegdheden, minstens operationeel, bijvoorbeeld via een centraal loket dat een 
gedeeld beleidsdoel op maat verdeelt tussen betrokken bevoegdheden en bevoegdheidsniveaus.

\subsection{Overlegrecht}

Persoonsrecht betekent gepersonaliseerde bescherming, geen collectieve standaardisering via sociaal overleg. Dat brengt ons bij een van de heikele politieke en maatschappelijke vragen van de toekomst van arbeidsrecht onder Werk 4.0: de toekomst van vakbonden. Op korte termijn staan vakbonden voor keuzes. Willen ze economische transformatie tegengaan, óf begeleiden? Willen ze de doorbraak van nieuwe arbeidsvormen en nieuwe zakenmodellen bestrijden om oude banen af te schermen, óf de arbeidsvoorwaarden van die nieuwe vormen en modellen bepleiten? Willen ze de digitale platformen inperken met minimale arbeidsbescherming ten bate van de minderheid van platformwerkers die er zijn hoofdactiviteit maakt, óf juist de flexibiliteit omarmen die werklozen, occasionele werkers en consumenten faciliteert? Willen ze nieuwe insiders maken en beschermen in de gig-economie, óf juist het potentieel voor het activeren van outsiders vrijwaren ${ }^{56}$ Willen ze een copy-paste van klassiek sociaal overleg in de meer associatieve context van freelancers, óf integendeel bijdragen tot persoonlijke loopbaanemancipatie ? $^{7}$

Op langere termijn is Werk 4.0 een existentiële bedreiging voor traditioneel overleg dat werknemers en werkgevers als doelgroep heeft. Historisch is collectieve vertegenwoordiging en onderhandeling een belangrijk vehikel geweest om de evolutie van arbeid en arbeidsvoorwaarden te managen in overleg en met een relatieve wapengelijkheid tussen de partijen. Een belangrijk neveneffect van Werk 4.0 is echter de ondermijning van de basisvoorwaarden van traditioneel sociaal overleg door veranderingen in arbeidsstructuren, bedrijfsstructuren en arbeidsstatuten. Naarmate werkpatronen de arbeidsovereenkomst achterlaten, zal het sociaal overleg ofwel natuurlijk wegdeemsteren, ofwel opnieuw moeten worden geïnstitutionaliseerd. ${ }^{58}$

Tegelijkertijd biedt Werk 4.0 kansen voor directe participatie en overleg, gefaciliteerd door dezelfde communicatietechnologie die de arbeid transformeert. Ook hierin loopt de platformeconomie voorop. Platformwerkers verenigen zich online, zonder enige aandacht voor hun persoonlijk juridisch statuut en ook zonder onderscheid van land of jurisdictie. ${ }^{59}$ We zien daarin het begin wat soms 'AltLabour' wordt genoemd: informele netwerkvakbonden die tegenover de flexibele platformeconomie een flexibele platformwerking voor acties en protest plaatsen.

Vergelijk de overwegingen in J. Sherk, Compulsory Union Representation Would Make Gig-Economy Jobs Less Flexible, The Heritage Foundation, Issue Brief 2016, nr. 4637.

57 Vgl. K. Stone, Unions in the Precarious Economy, Prospect 2017.

58 Zie V. De Stefano \& A. Aloisi, Fundamental Labour Rights, Platform Work and Human-Rights Protection of Non-Standard Workers, Bocconi University Legal Studies Research Paper 2018.

59 Zie bijvoorbeeld Turkopticon, FairCrowdwork Watch, UberPeople en diverse Facebook-groepen. Voor een overzicht, zie H. Johnston \& C. Land-Kazlauskas, Organizing On-Demand: Representation, Voice, and Collective Bargaining in the Gig Economy, ILO, Conditions of work and employment series 2018, nr. 94; K. Vandaele, Will trade unions survive in the platform economy?, ETUI, Working Paper 2018.05. 
Netwerkvakbonden gedragen als gebruikersorganisaties of lobbygroepen om bedrijven tot concessies en overheden tot acties te dwingen. Niet langer sociaal overleg in de strikte zin, maar economische belangenverdediging die bedrijfsmuren en contractuele verhoudingen overstijgt: een echo van de gilden in de 21ste eeuw. Vakbondsprotest tegen bedrijven zoals Uber of Airbnb is evenzeer een protest voor economische reglementering als tegen arbeidspraktijken.

Netwerkvakbonden lijken nogal op economische kartelvorming. Ze kunnen op gespannen voet staan met competitierecht dat alleen voor collectieve arbeidsovereenkomsten tussen werkgevers en werknemers een uitzondering maakt op de marktregels die kartels verbieden. ${ }^{60}$ Prijsafspraken met en tussen zelfstandige dienstverleners blijven fundamenteel problematisch in een markteconomie. De internetplatformen zijn trouwens zelf draaischijven voor georganiseerde prijsafspraken en neigen naar natuurlijke monopolies, wat hun economische legitimiteit intrinsiek onzeker maakt. De toekomst van arbeidsrecht is zo gekoppeld aan de toekomst van marktrecht dat het ook met nieuwe grensvragen wordt geconfronteerd en waarin de klassieke rol van vakbonden en sociaal overleg muteert.

Werk 4.0 zal ons uiteindelijk dwingen om het recht op overleg en onderhandeling te herdefiniëren. In plaats van defensieve obstructie kunnen vakbonden daarin positief het voortouw nemen. Als de loopbaan het leidmotief wordt, kunnen vakbonden loopbaandiensten ontwikkelen die arbeidsstatuten overstijgen. Als personen laveren tussen banen en statuten, kunnen vakbonden voor hen sociale bescherming poolen en organiseren, zoals ze dat historisch hebben gedaan vóór de opkomst van de welvaartsstaat. Als werknemers in de toekomst hun eigen werkgever zullen worden, kunnen vakbonden werknemersbescherming bieden via coöperaties waarin mensen zich kunnen verenigen voor verzekering. ${ }^{61}$ Als Werk 4.0 mens en machine versmelt, kunnen vakbonden ijveren om die versmelting niet alleen productief maar ook kwalitatief te maken: een agenda voor menselijke en inclusieve robotisering. ${ }^{62} \mathrm{Als}$ platformen mensen rechtstreeks voor bedrijven en consumenten laten werken, kunnen vakbonden streven voor autoregulering en certificaten die platformen labelen op arbeidsvoorwaarden en die klanten daarin sensibiliseren.

Collectief overleg kan zich dus positief spiegelen aan de nieuwe kerntaken van het arbeidsrecht: loopbaanbeheer, kwaliteitsbewaking, talentontwikkeling en individuele rechten. De huidige evolutie naar gedecentraliseerd overleg met de klemtoon op het bedrijfsniveau, waarneembaar in veel Europese landen, is daarvoor een aanzet. Het onderscheid tussen werknemers en zelfstandigen zal ook voor sociale partners geleidelijk vervagen of vervlieden. We zullen moeten kiezen: het sociaal overleg over arbeidsvoorwaarden ofwel verbreden als deel van het persoonsrecht dat arbeidsstatuten overstijgt, ofwel transformeren als economisch

60 Zie M. De Vos, European Social Dialogue and European Competition Law: an Inherent Contradiction?, in: M. De Vos (red.), A Decade Beyond Maastricht: The European Social Dialogue Revisited, Den Haag: Kluwer Law International 2003; Johnston \& Land-Kazlauskas 2018.

61 Frankrijk kent al de 'coopérative d'activité et d'emploi': zie wet nr. 2014-856 van 31 juli 2014; J.-Y. Kerbourc'h \& E. Prouet, Les tiers dans la relation de travail: entre fragmentation et sécurisation, France Stratégie, Note d'analyse 2018, nr. 65.

62 C. Degryse, Shaping the world of work in the digital economy, ETUI Foresight Brief 2017. 
overleg, ofwel laten eroderen tot een permanent verzetsinstrument tegen de veranderingen van Werk 4.0.

\section{De toekomst als keuze}

Samenlevingen, organisaties, bedrijven en personen zijn dus geen passieve toeschouwers die Werk 4.0 ondergaan, maar actieve spelers die Werk 4.0 maken. De investeringsbeslissingen van landen en bedrijven, de voorschriften voor veiligheid, privacy en interactie tussen mens en machine, de integratie van technologie in de arbeidsorganisatie, de prioriteiten en beslissingen van burgers: het ligt in onze handen. Onze individuele en collectieve keuzes zullen de toekomst van arbeid en arbeidsrecht bepalen.

In plaats van ons af te vragen hoe robots en AI de mens kunnen bedreigen, zouden we ons moeten afvragen hoe we robots en AI kunnen gebruiken om de mens te helpen en te verbeteren. In plaats van obsessief te piekeren over welke jobs gedoemd zijn te verdwijnen, zouden we moeten nagaan hoe we dankzij technologie anders en beter kunnen gaan werken. De disruptieve megatrends achter Werk 4.0 zijn een kans en een opdracht, voor iedereen, om strategisch en op lange termijn de vraag te beantwoorden: voor welke toekomst van arbeid willen we kiezen? Deze bijdrage poogt het antwoord op die vraag te structureren door de identificatie van kernassen: activering 2.0, loopbaanrecht, arbeidskwaliteitsrecht, talentrecht, activiteitsrecht, persoonsrecht en overlegrecht.

De meest fundamentele keuze betreft de positie die arbeid inneemt in economie en samenleving. Deze bijdrage begon met een identificatie van trends die de wereld van werk transformeren. Die transformatie interpelleert omdat niet alleen de economie, maar ook de sociale zekerheid en het persoonlijk welzijn in onze samenleving gebaseerd zijn op betaald werk. Het historische compromis tussen kapitalisme en socialisme heeft welvaartsstaten gebracht die werkelijk verslaafd zijn aan economische groei en zijn afgeleide, betaalde arbeid.

Slechts doordat productieve economische arbeid de basis van welvaart en welzijn vormt, moet deze bijdrage geschreven worden. Een revolutionair alternatief voor de toekomst van arbeid en arbeidsrecht is daarom het doorknippen van de navelstreng tussen economie, inkomen en bescherming aan de ene kant, en arbeid aan de andere kant. Daarvoor staat het utopische idee van een universeel basisinkomen. Ik deel niet de utopie, maar zeker de onderliggende bekommernis over de rol van arbeid in de moderne welvaartsstaat. ${ }^{63}$

Als recht op gezondheidszorg, opleiding, vorming, begeleiding, activering en zo meer alleen via reguliere arbeid wordt verworven, riskeert Werk 4.0 op grote schaal activiteit, welvaart en welzijn te bedreigen. Vandaar mijn pleidooi voor algemene, gepersonaliseerde en draagbare activeringsrechten, loopbaanrechten en talentrechten die alle peripetieën van werk en leven overbruggen. Het 'personaliseren' van arbeidsbescherming hangt al enige tijd in de lucht als een instru- 
ment voor sociale inclusie bij economische turbulentie. ${ }^{64}$ Ik trek die insteek door en verbreed hem. Vandaar mijn voorspelling dat het arbeidsrecht van de toekomst meer wordt dan arbeidsrecht alleen. Het zal opgaan in, en combineren met, een transversale beleidsfocus op persoonlijke talentontwikkeling voor en doorheen de loopbaan.

In essentie moet het sociaal contract over de rol van arbeid en tewerkstelling in onze samenleving evolueren. Grotere variatie en verandering van banen betekent dat sociaal beleid niet alleen dient voor wie geen baan heeft, maar ook voor wie wel een baan heeft. Het klassieke model van een welvaartsstaat die de gaten opvult na en tussen banen moet evolueren naar een investeringsstaat die doorlopend, anticiperend en preventief bescherming biedt. Vandaar de motto's van loopbaanrecht en talentrecht.

Arbeidsrecht staat voor de keuze om Werk 4.0 te begeleiden of te stremmen. De wijze waarop landen, regio's, sociale partners en bedrijven met arbeidsregulering en arbeidsorganisatie omgaan, zal een belangrijke factor zijn voor succes of falen onder Werk 4.0. De wijze waarop de toekomstige rol van vakbonden en sociaal overleg wel of niet institutioneel invulling krijgt, zal een belangrijke factor zijn voor de sociale aanpassing van Werk 4.0 aan menselijke noden en wensen. Kiezen over de toekomst van arbeid is ook kiezen over de toekomst van sociaal overleg. ${ }^{65}$ Arbeidsrecht dat Werk 4.0 omarmt, zal zichzelf transformeren door te personaliseren. De focus wordt de mens die minder arbeidskracht ter beschikking stelt van een organisatie en die meer rechtstreeks economisch ageert. Arbeid was geen koopwaar, maar wordt ook koopwaar wanneer Werk 4.0 de tussenschakels van menselijke samenwerking en organisatie laat verdampen of variëren.

We mogen niet vervallen in reductionisme. Werk 4.0 is veel meer dan een arbeidsvraagstuk. De toekomst van arbeid is aan veel meer dan de regulering en organisatie van arbeid gebonden. We zullen als samenleving meer holistisch met technologische transformatie omgaan, in economie, milieu, politiek, ethiek, zowel cultureel als sociaal en juridisch. We zullen arbeid en loopbaan moeten leren zien en beheren als een continuüm dat in alle levensfasen leeft.

We mogen evenmin veralgemenen. Er wacht ons geen totale revolutie die alles en iedereen gelijk treft. Regionale verschillen zullen belangrijker worden omdat samenlevingen algemeen verstedelijken en omdat steden de deeltjesversnellers van innovatie zijn. ${ }^{66}$ Sectoren, groepen en beroepen zullen verdwijnen, krimpen, groeien, upgraden, versnipperen, digitaliseren, internationaliseren. Daarbij zullen nieuwe breuklijnen ontstaan. Het is niet denkbeeldig dat de realiteit van Werk 4.0 gedomineerd wordt door specifieke problemen die leiden tot specifieke oplossingen: de toekomst van transport, de rol van banken, technologie in de zorg, de positie van ouderen, de laaggeschoolden. ${ }^{67}$

64 Zie en vergelijk bijvoorbeeld A. Supiot e.a., Beyond Employment. Changes in work and the future of labour law in Europe, Oxford University Press 2001.

65 Zie ILO 2017, p. 22 e.v.

66 Zie bijvoorbeeld Shift: The Commission on Work, Workers, and Technology, Report of Findings 2017.

67 In die zin bijvoorbeeld PwC 2018. 
Het potentieel van geavanceerde robots hangt bijvoorbeeld sterk samen met de aard van de bedrijfsactiviteit en de kostprijs van arbeid, nog daargelaten de investeringskracht, strategie en organisatie van de bedrijven. Daarom zal voorzienbare robotisering vooral in specifieke industriële sectoren en specifieke productielanden plaatsvinden. ${ }^{68}$ In voorkomend geval betekenen robots een productiviteitsverbetering binnen een economisch weefsel dat al sterk gerobotiseerd is: de voortzetting van een gekende trend, met gekende maar meer acute noden van talentontwikkeling en loopbaanondersteuning voor bijzondere groepen en regio's.

Ik verwacht dat de keuzes rond zogezegde 'oudere' werknemers op de arbeidsmarkt fundamenteel zullen kenteren. Werk 4.0 kruist een verouderende schaarse beroepsbevolking met technologische revolutie. De toekomst van arbeid is vooral ouder en we zullen de ouderen broodnodig hebben. De last van 'langer werken' omdat het moet, wordt de lust van langer werken omdat het kan. Technologie die nu vaak ouderen negeert, zal ouderen moeten mobiliseren. Dat betekent werken op maat, loopbanen die meanderen, rollen die evolueren en het vermengen van activiteit en pensioen.

Werk 4.0 is ook, en misschien zelfs vooral, een psychologische switch voor de mens. Het archetype van 'de baan', zijnde een functionele rol in een organisatie, met een set van verantwoordelijkheden, functionele competenties, een titel, een niveau en een carrièrepad, verwatert. In de plaats komen taken, projecten, doelstellingen, teams en resultaten. Dat biedt meer variatie, meer keuze, meer opties. Maar dat gaat niet vanzelf. Werken op mensenmaat maakt arbeid zowel gemakkelijker als moeilijker. We krijgen meer controle over arbeid, maar daardoor ook meer verantwoordelijkheid. Er is geen alternatief voor presteren.

Om succesvol te zijn zullen we moeten leren onszelf te organiseren en te managen, zonder het comfort van een ondersteunende organisatie en professionele gemeenschap. Dat vergt zowel praktische als mentale discipline. ${ }^{69}$ De dartelende 'gig-werker' is een veelzijdige 'gig-zelfmanager'. Dat vergt een leerproces dat belangrijk zal zijn voor de kwaliteit van arbeid onder Werk 4.0. Talentontwikkeling en persoonlijk welzijn ondersteunen elkaar. Werk 4.0 kan de wereld van arbeid zowel toegankelijker, inclusiever, gevarieerder, productiever, geëmancipeerder, kwalitatiever als vrijer maken. Maar we moeten er wel voor kiezen.

69 Zie G. Petriglieri e.a., Agony and Ecstasy in the Gig Economy: Cultivating Holding Environments for Precarious and Personalized Work Identities, Administrative Science Quarterly 2018. 